\title{
Historical Perspective on How and Why Switchgrass was Selected as a "Model" High-Potential Energy Crop
}

\author{
July 2007
}

Prepared by Lynn Wright Consultant to Bioenergy Resources and Engineering Systems Environmental Sciences Division

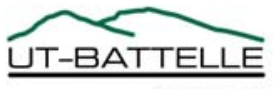

ORNL-27 (4-00) 


\title{
DOCUMENT AVAILABILITY
}

Reports produced after January 1, 1996, are generally available free via the U.S. Department of Energy (DOE) Information Bridge.

Web site http://www.osti.gov/bridge

Reports produced before January 1, 1996, may be purchased by members of the public from the following source.

\author{
National Technical Information Service \\ 5285 Port Royal Road \\ Springfield, VA 22161 \\ Telephone 703-605-6000 (1-800-553-6847) \\ TDD 703-487-4639 \\ Fax 703-605-6900 \\ E-mail info@ntis.gov \\ Web site http://www.ntis.gov/support/ordernowabout.htm
}

Reports are available to DOE employees, DOE contractors, Energy Technology Data Exchange (ETDE) representatives, and International Nuclear Information System (INIS) representatives from the following source.

Office of Scientific and Technical Information

P.O. Box 62

Oak Ridge, TN 37831

Telephone 865-576-8401

Fax 865-576-5728

E-mail reports@osti.gov

Web site http://www.osti.gov/contact.html

This report was prepared as an account of work sponsored by an agency of the United States Government. Neither the United States Government nor any agency thereof, nor any of their employees, makes any warranty, express or implied, or assumes any legal liability or responsibility for the accuracy, completeness, or usefulness of any information, apparatus, product, or process disclosed, or represents that its use would not infringe privately owned rights. Reference herein to any specific commercial product, process, or service by trade name, trademark, manufacturer, or otherwise, does not necessarily constitute or imply its endorsement, recommendation, or favoring by the United States Government or any agency thereof. The views and opinions of authors expressed herein do not necessarily state or reflect those of the United States Government or any agency thereof. 
ORNL/TM-2007/109

Environmental Sciences Division

\section{HISTORICAL PERSPECTIVE ON HOW AND WHY SWITCHGRASS WAS SELECTED AS A "MODEL" HIGH-POTENTIAL ENERGY CROP}

Lynn Wright,

Consultant to Bioenergy Resources and Engineering Systems

Date Published: August 2007

Prepared by

OAK RIDGE NATIONAL LABORATORY

Oak Ridge, Tennessee 37831-6283

managed by

UT-BATTELLE, LLC

for the

U.S. DEPARTMENT OF ENERGY

under contract DE-AC05-00OR22725 
[Blank page—do not page number blank backup pages] 


\section{CONTENTS}

Page

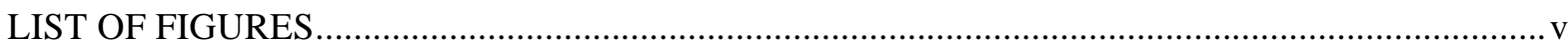

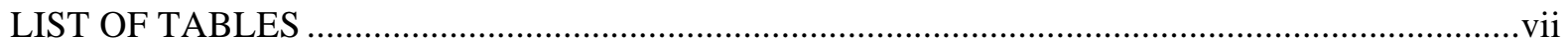

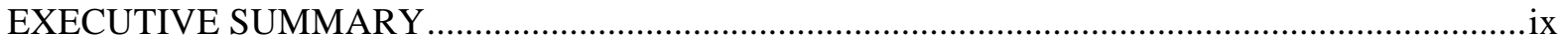

ABSTRACT …

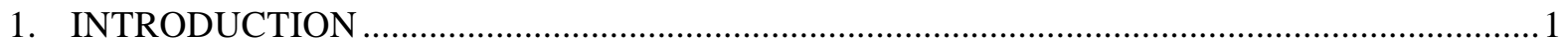

1.1 BIOFUELS FEEDSTOCK DEVELOPMENT PROGRAM BACKGROUND ....................2

1.2 GOALS OF THE HERBACEOUS CROPS PROGRAM SOLICITATION .......................2

2. HERBACEOUS CROP SCREENING..................................................................................

2.1 DESCRIPTION OF THE HERBACEOUS SCREENING PROJECTS …......................... 4

2.2 SCREENING TRIAL RESULTS AND RECOMMENDATIONS...................................... 7

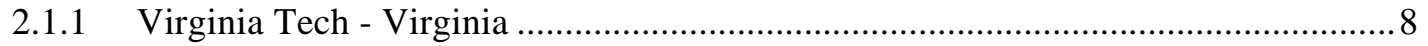

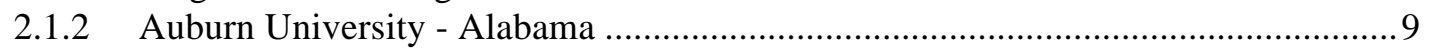

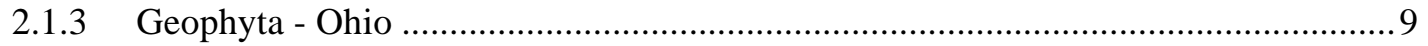

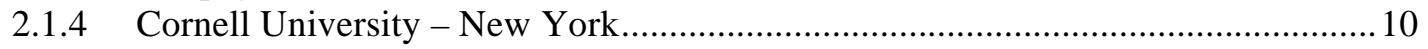

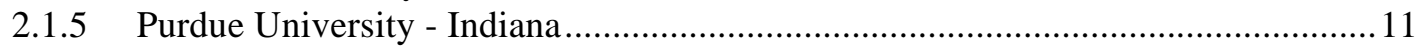

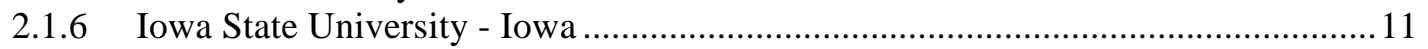

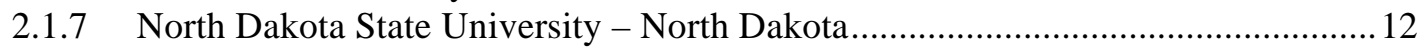

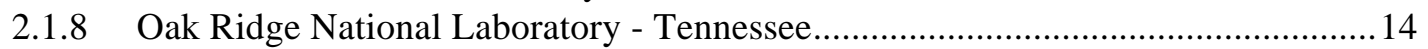

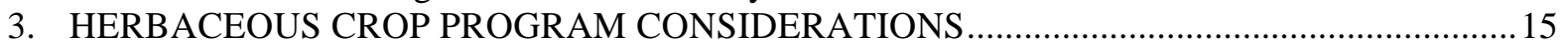

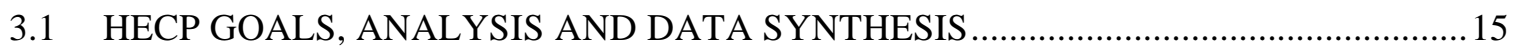

3.2 BFDP FUNDING EFFECTS ON MODEL SPECIES SELECTION …............................ 18

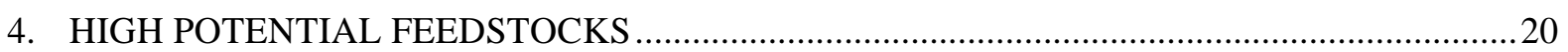

4.1 HERBACEOUS CROPS CONSIDERED HIGH POTENTIAL IN 2006..........................20

4.2 BIOFUELS FEEDSTOCK SELECTION CRITERIA ….............................................. 21

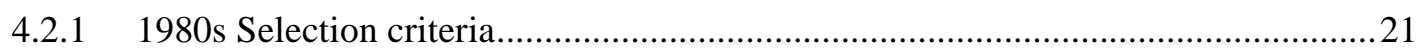

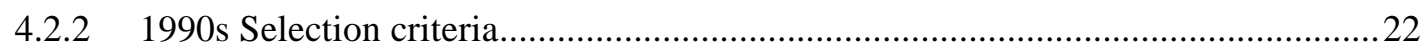

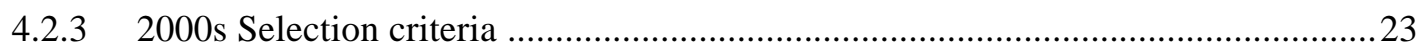

5. CHARACTERISTICS OF THE SWITCHGRASS "MODEL"

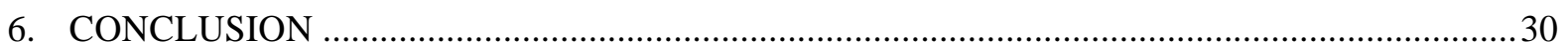

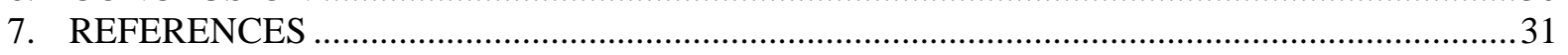

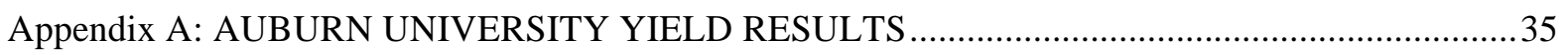

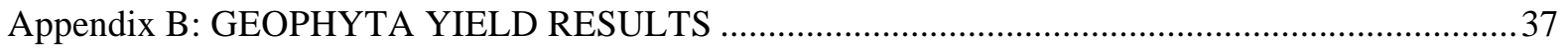

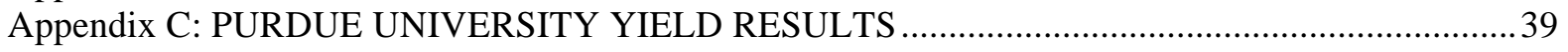

Appendix D: IOWA STATE UNIVERSITY YIELD RESULTS ….............................................. 41

Appendix E: NORTH DAKOTA STATE UNIVERSITY YIELD RESULTS ................................ 43 
[Blank page—do not page number blank backup pages] 


\section{LIST OF FIGURES}

Figure

Page

1 Location of herbaceous crops field testing sites.

4

2 Woody and herbaceous species considered by the Department of Energy's Biofuels Feedstock Development Program in 1991 as having high potential as energy crop feedstocks .18

3

Funding History of the Biofuels Feedstock Development Program between 1978 and 1998. 
[Blank page—do not page number blank backup pages] 


\section{LIST OF TABLES}

Table

Page

$1 \quad$ Species screened by the Herbaceous Crops Program between 1986 and $1992 \ldots \ldots \ldots \ldots \ldots \ldots . . . .5$

2 Descriptions of herbaceous crop screening test sites .................................................. 6

3 Mean biomass yield averaged across 12 sites for eight herbaceous biomass species

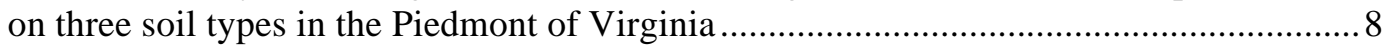

4 Average yields of the three highest-yield consecutive years during the first 5 years of production of perennial biomass crops grown in the eastern Great Lakes Region ........ 10

5 Yields of herbaceous biomass crops grown at four sites in Indiana during the drought year of 1988

Costs and break-even prices of the crop production systems evaluated in Iowa 1988-1992

Computed soil loss (mean of three sites) of eight no-till-planted species at four locations (three soils) in the Piedmont

8 Estimated soil loss under thirteen crop systems at two Iowa locations using the Universal Soil Loss Equation (USLE)

Species recommended for further development or study by the seven herbaceous screening projects

10 Feedstock criteria, criteria relevance categories, and ranking (high, medium and low) of the capability of switchgrass to meet those criteria for cellulosic ethanol production systems 
[Blank page—do not page number blank backup pages] 


\section{ACKNOWLEDGMENTS}

Thanks to Anthony Turhollow, Shahabaddine Sokhansanj, Ethan Davis, Robert Perlack and Mark Downing for their reviews of the document. Much credit goes to Janet Cushman, Anthony Turhollow, Sandy McLaughlin and Lynn Kszos for the many reports and papers on herbaceous crops they prepared during their tenures as manager and/or project leaders of herbaceous crops research at ORNL during the 1980s and 1990s. Those documents provided a great deal of the information summarized in this paper. Much credit also goes to the many researchers who carried out the herbaceous crops screening trials and concluded those trials with excellent report documenting the results. I thank the current managers of the biomass research effort at Oak Ridge National Laboratory (ORNL), Jonathon Mielenz and Mark Downing, for allowing me the opportunity to continue to contribute to the biomass effort by providing historical documentation of a significant decision made by the program during my tenure as a biomass research leader at ORNL. Most importantly, I would also like to acknowledge the long term support of energy crops research since 1978 by the Department of Energy's Biomass Program within the office of Energy Efficiency and Renewable Energy and particularly the support of John Ferrell, Sarah Sprague and other feedstock program managers.

\section{EXECUTIVE SUMMARY}

The screening trials funded by the U.S. Department of Energy in the late 1980s to early 1990s assessed a wide range of about 34 species with trials being conducted on a wide range of soil types in 31 different sites spread over seven states in crop producing regions of the U.S. While several species were identified as having merit for further development, the majority of institutions involved in the herbaceous species screening studies identified switchgrass as having high priority for further development. Six of the seven institutions either included switchgrass among the 2-3 species with highest potential in their region, or recommended that further research be done on switchgrass in their region. All institutions recommended that perennial grasses be given high research priority. The Virginia and Alabama projects, had the most success with switchgrass and produced some of the most persuasive information showing the merits of switchgrass - especially the potential for high yields, its deep rooting characteristics, and its potential value in carbon sequestration. The projects in Indiana, Iowa, and North Dakota all came to the conclusion that switchgrass merited further development as a bioenergy crop primarily after conducting economic analysis, since visual results of crop yields most often led toward favoring sorghum systems. In some cases, additional characteristics such as more favorable conversion characteristics or lower erosion potential increased the interest in switchgrass. In the case of the projects in Ohio and New York, both with several poorly drained test sites, the case for switchgrass was not as strong due to problems with establishment and weed control. The New York project did conclude that switchgrass had desirable characteristics and should receive more evaluation in the region. The Geophyta project did not include switchgrass among the top three yielding crops in their trials, but it was the $4^{\text {th }}$ best performer and was achieving yields equivalent to or greater than other crops by the $4^{\text {th }}$ year of the study. The other crop(s) which were identified as having high potential by several of the projects included some type of sorghum (sweet sorghum, forage sorghum or sorghum x sudangrass) and reed canarygrass. Additionally, there were a few species or species mixtures unique to a single site that appeared to merit further consideration such as sericea lespedeza and energy cane in Alabama and alfalfa/bromegrass in New York. The Oak Ridge project and at least three of the screening projects also identified mixed species "meadow", "old field" or "weed" trials as possibly being economically viable production systems even though yields were relatively low.

Economic and environmental assessments by Oak Ridge National Laboratory's Biofuels Feedstock Development Program staff together with the screening project results and funding limitations lead to 
making the decision in 1991 to invest future Department of Energy research funds primarily in switchgrass as a "model" or "prototype" bioenergy crop. This selection was justified in the 1992 Annual Progress Report ${ }^{(1)}$ of the Department of Energy's Biofuels Feedstock Development Program (BFDP) with the following statement:

"In 1984, a series of ten herbaceous research projects began at widespread locations across the eastern and Midwestern United States. A total of 35 species was examined in these initial screening studies, which were designed to examine yield potential, biochemical composition, and best management practices across a wide diversity of sites. The completion of several of these studies and the examination of data on yield potential, production economics, and regional site potential, led in 1991 to the selection of a perennial forage grass switchgrass as a model species for further research.

The rational for selection of a single species was to concentrate and thereby improve the overall efficiency of the many interrelated aspects of research that were seen as requisite for biofuels production. Although more than one species will certainly be required ultimately, switchgrass was seen as an excellent beginning with the available programmatic resources.

The selection of switchgrass as a model species was based on several important considerations. As a widely adapted endemic species of the tall grass prairies, switchgrass has demonstrated a capacity for high yields on relative poor quality sites. Maximum annual yields on test plots in Auburn, Alabama, have been 33 dry $\mathrm{Mg} \mathrm{ha}^{-1}$, well above the production level considered prerequisite for a successful biofuels industry. A large and deep root system is the key to high production and soil improvement on poor quality sites. Research at Virginia Polytechnic Institute and State University has shown that soil organic carbon was increased by $30 \%$ during a 4-year cycle, indicating that switchgrass has a significant capacity to improve soil quality by sequestering carbon belowground. Improved erosion control, reduced fertilizer and pesticide requirements and a capacity for providing wildlife cover are additional positive environmental attributes. An important quality of switchgrass is its strong potential appeal to landowners, for whom cultivation of a perennial crop that can be grown, harvested, and stored with conventional equipment represents an easy interface with current agricultural practices."

It should be noted that the exceptionally high yield of 33 dry $\mathrm{Mg} \mathrm{ha}^{-1}$ was not an outcome of the original herbaceous screening trials, but was observed in 1989 in a $2^{\text {nd }}$ year switchgrass variety trial established by Auburn University in 1988, mid-way during the screening trial phase of work. The results were published in 1991. ${ }^{(2)}$ This variety trial showed that the original switchgrass variety chosen for the screening trials (Cave-in-Rock) was probably not the best selection for many of the screening locations. The high yield potential of the new variety, Alamo, was first identified by the Auburn trial.

Selection of switchgrass as a model species in 1991 lead to a switchgrass specific solicitation and then to 10 years of switchgrass development at ten institutions under the management of Sandy McLaughlin and others at ORNL. ${ }^{(3)}$ More recently switchgrass has been the focus of investigations at several additional universities and private institutions. New varieties have been developed and released, management techniques have been improved, and much more is now known about how switchgrass can be harvested, handled, stored and converted to ethanol or used to produce power. Now, in 2007, it is very apparent that while switchgrass may not be a perfect energy crop (and there may not be a perfect crop), it has many valuable characteristics that will result in its continuing to be not only a "model or prototype" for crop development, but also one of the more sustainable feedstocks for the production of renewable alternative fuels in the U.S. 
[Blank page—do not page number blank backup pages] 



\begin{abstract}
A review of several publications of the Biofuels Feedstock Development Program, and final reports from the herbaceous crop screening trials suggests that there were several technical and non-technical factors that influenced the decision to focus on one herbaceous "model" crop species. The screening trials funded by the U.S. Department of Energy in the late 1980s to early 1990s assessed a wide range of about 34 species with trials being conducted on a wide range of soil types in 31 different sites spread over seven states in crop producing regions of the U.S. While several species, including sorghums, reed canarygrass and other crops, were identified as having merit for further development, the majority of institutions involved in the herbaceous species screening studies identified switchgrass as having high priority for further development. Six of the seven institutions included switchgrass among the species recommended for further development in their region and all institutions recommended that perennial grasses be given high research priority. Reasons for the selection of switchgrass included the demonstration of relatively high, reliable productivity across a wide geographical range, suitability for marginal quality land, low water and nutrient requirements, and positive environmental attributes. Economic and environmental assessments by Oak Ridge National Laboratory's Biofuels Feedstock Development Program staff together with the screening project results, and funding limitations lead to making the decision to further develop only switchgrass as a "model" or "prototype" species in about 1990. This paper describes the conditions under which the herbaceous species were screened, summarizes results from those trials, discusses the various factors which influenced the selection of switchgrass, and provides a brief evaluation of switchgrass with respect to criteria that should be considered when selecting and developing a crop for biofuels and bioproducts.
\end{abstract}

\title{
1. INTRODUCTION
}

Switchgrass was selected as a "model" energy crop species deserving of further research in 1991. This selection was briefly explained and justified in at least three previous publications of Oak Ridge National Laboratory including the 1992 Annual Progress Report ${ }^{(1)}$ of the BFDP, a proceedings paper published in $1992,{ }^{(4)}$ and the switchgrass research summary paper published in $2005 .{ }^{(3)}$

The 1992 proceedings paper by McLaughlin ${ }^{(4)}$ described several important considerations for selecting switchgrass as the model species. A very important one was that the land base for switchgrass was believed to be quite large and varied because of demonstrated high yields on relatively poor quality sites and because of its deep rooting characteristic. McLaughlin noted that the land most likely to be used for herbaceous crop production is the approximately 48 million acres of marginal land that has severe restrictions for conventional crop production. Given the assumption that such land would be utilized for production of switchgrass, then a wide range of environmental benefits could occur including improvement of soil carbon by sequestering carbon belowground, improved erosion control, reduced fertilizer and pesticide requirements (relative to conventional annual crops), and a capacity for providing wildlife cover. Similar reasons were described in the 1982 Annual Progress Report of the BFDP and quoted in the executive summary of this document.

The focus on a single species was a departure from the original strategy envisioned by the managers of the Herbaceous Crops Program (HECP) at Oak Ridge National Laboratory (ORNL). A 1991 paper presented by the ORNL Herbaceous Crops Program managers at a national biomass meeting ${ }^{(5)}$ described the desirability of selecting at least one annual, one perennial, and one legume for further research.

A review of several publications of the Biofuels Feedstock Development Program, and final reports 
from the Herbaceous Crop screening trials suggests that there were both technical and non-technical factors that influenced the decision to focus on one herbaceous "model" crop species. This paper will summarize reported results, discuss the various factors which influenced the selection of switchgrass, and provide a brief updated evaluation of switchgrass with respect to selection criteria considered important then and now.

\subsection{BIOFUELS FEEDSTOCK DEVELOPMENT PROGRAM BACKGROUND}

The Department of Energy became involved in supporting the development of biomass resources as early as 1976 when DOE's Biomass Systems Branch initially funded several systems analysis studies on sugar crops, agricultural residues, wood energy farms, grains and grasses and aquatic plant production. DOE's first funded field studies on bioenergy crops in 1977 by co-funding work that had been initiated by USDA on woody crops, sugar cane, and tropical grasses. DOE quickly established its own energy crop research effort with the issuance of two Program Research and Development Announcements on "Fuels from Woody Biomass" and "Fuels from Aquatic Species". Oak Ridge National Laboratory was asked by DOE in 1978 to provide advice and support in the selection and management of the woody biomass projects and the Solar Energy Research Institute supported the aquatic research effort. By 1982, DOE had fully transferred technical and administrative management of the Short Rotation Woody Crops Program to ORNL and by 1984, DOE provided funds to ORNL to develop an Herbaceous Energy Crops Program.

Prevailing assumptions in the early 1980s about best potential herbaceous energy crops species are documented by a publication entitled "The Production of Herbaceous Feedstocks for Renewable Energy", published September 1986 by the Solar Energy Research Institute. ${ }^{(6)}$ This document described the major reasons for interest in herbaceous crops including: (1) the idea that it would be relatively easy for the agricultural production sector to switch to production of herbaceous biomass crops, (2) the assumption that alternative crops could be attractive to a depressed farm economy, and (3) that herbaceous crops might be more suitable than woody crops as feedstocks for fermentation alcohol and anaerobic digestion. However, it is interesting that the twelve "representative" herbaceous crops described by the SERI document ${ }^{(6)}$ included crops grown for both carbohydrate and cellulosic components. The carbohydrate crops included sugarcane, sweet sorghum, sweet-stemmed grain sorghum, Jerusalem artichoke, sugar beets, and fodder beets. The lignocellulosic crops described included kenaf, napiergrass, alfalfa, reed canarygrass, common reed, and water hyacinth. After reviewing all of the pros and cons of various approaches, the Herbaceous Crops Program Managers at ORNL chose to develop a program solicitation that excluded crops grown primarily for carbohydrates and instead chose to solicit proposals limited to research on cellulosic crops. The goals of the original program solicitation were very important to setting the agenda and the basic criteria for selecting species for further development.

\subsection{GOALS OF THE HERBACEOUS CROPS PROGRAM SOLICITATION}

The Herbaceous Energy Crops Program (HECP) was initiated in 1984 with a request for proposals (RFP) focused on the southeast (exclusive of subtropical areas) and the Midwest/lake States. ${ }^{(7)}$ The focus on grass and legume herbage was based on a government report ${ }^{(8)}$ that had identified these biomass resources as second in size only to wood. The overall goal of the HECP was stated to be "to develop data and information that will lead to commercially viable systems for producing herbaceous biomass for fuels and energy feedstocks." A very important element of the HECP was the desire to achieve the goal in ways that would minimize adverse environmental effects. ${ }^{(9)}$ The direction of the

HECP and some of the important criteria were clearly established in the technical discussion section of the initial $\operatorname{RFP}^{(7)}$ as evidenced by the following words in the proposal description: 
"Three major factors influenced the initial focus of research in the program. First was the desire to increase the production of biomass for energy without significantly reducing food production. This led to the decision to concentrate on species for marginal croplands and on species that can be grown as winter crops. Second was the decision to produce fuels or energy feedstocks rather than chemicals. This meant the program would initially include a minimum of research on hydrocarbon crops, because evaluations of hydrocarbon-producing species that will grow in the United States have concluded that the hydrocarbon productions will be more valuable as specialty chemicals, primarily lubricants, than fuels. Third was the desire to have the greatest possible impact on total biomass energy use. This led to the decision to emphasize lignocellulosic crops."

Proposals were scored on the basis of (1) demonstration of a through understanding of the proposed work, (2) application of the proposed work of the Herbaceous Energy Crops Program to the targeted regions, (3) the degree of private sector participation, (4) qualifications of the personnel, and (5) availability of facilities and equipment.

While the initial work focused on screening species to identify high-potential candidates, the solicitation's statement of work ${ }^{(7)}$ recommended that different intensities of management be part of the initial screening process. The statement of work also clarified that while the focus was on marginal land, the proposals should include a range of site types, including some good agricultural land, so that relationships among site quality, management inputs, and yields could be established. Land was considered to be marginal if it was limited by erosiveness, excessive wetness, soil chemistry constraints, rooting constraints, or climate issues. While the original $\mathrm{RFP}^{(7)}$ did not explicitly state that environmental concerns would be a factor in the selection of species for further research, the fact that an evaluation of soil loss potential was a required component of the proposals demonstrated a concern for environmental effects of the cropping systems.

Responsive proposals were required to screen at least two species, one of which had to be a forage or hay crop commonly grown in the test site region. The other crop(s) could be annual or perennial and they could be common or less common species, however their inclusion had to be explained and justified. Thirteen proposals were received from a total of twelve institutions. Several of those were deemed not responsive to the $\mathrm{RFP}^{(7)}$ either because of the species proposed or because the trials would be located in sub-tropical regions of the country. Thus, only seven proposals merited serious review. Five organizations were selected to participate in the southeastern and Midwest species screening trials that began in 1985 . The HECP annual report for $1985^{(10)}$ described the recently initiated herbaceous crop screening research projects and defended the rational for focusing the research in the southeast and Midwest/lake areas. Those regions were chosen for study because large areas of marginal cropland are potentially available and there are relatively few environmental restrictions on productivity. In 1988, two additional institutions were added to the species screening effort to achieve a broader coverage of potentially available site types. 


\section{HERBACEOUS CROP SCREENING}

\subsection{DESCRIPTIONS OF THE HERBACEOUS SCREENING PROJECTS}

Six universities and one private company were selected to participate in the herbaceous screening projects (Fig. 1). The universities included Cornell University, Virginia Polytechnic Institute and State University (referred to as Virginia Tech), Auburn University, Purdue University, Iowa State University, and North Dakota State University. The seventh research group was a small company in Ohio named Geophyta.

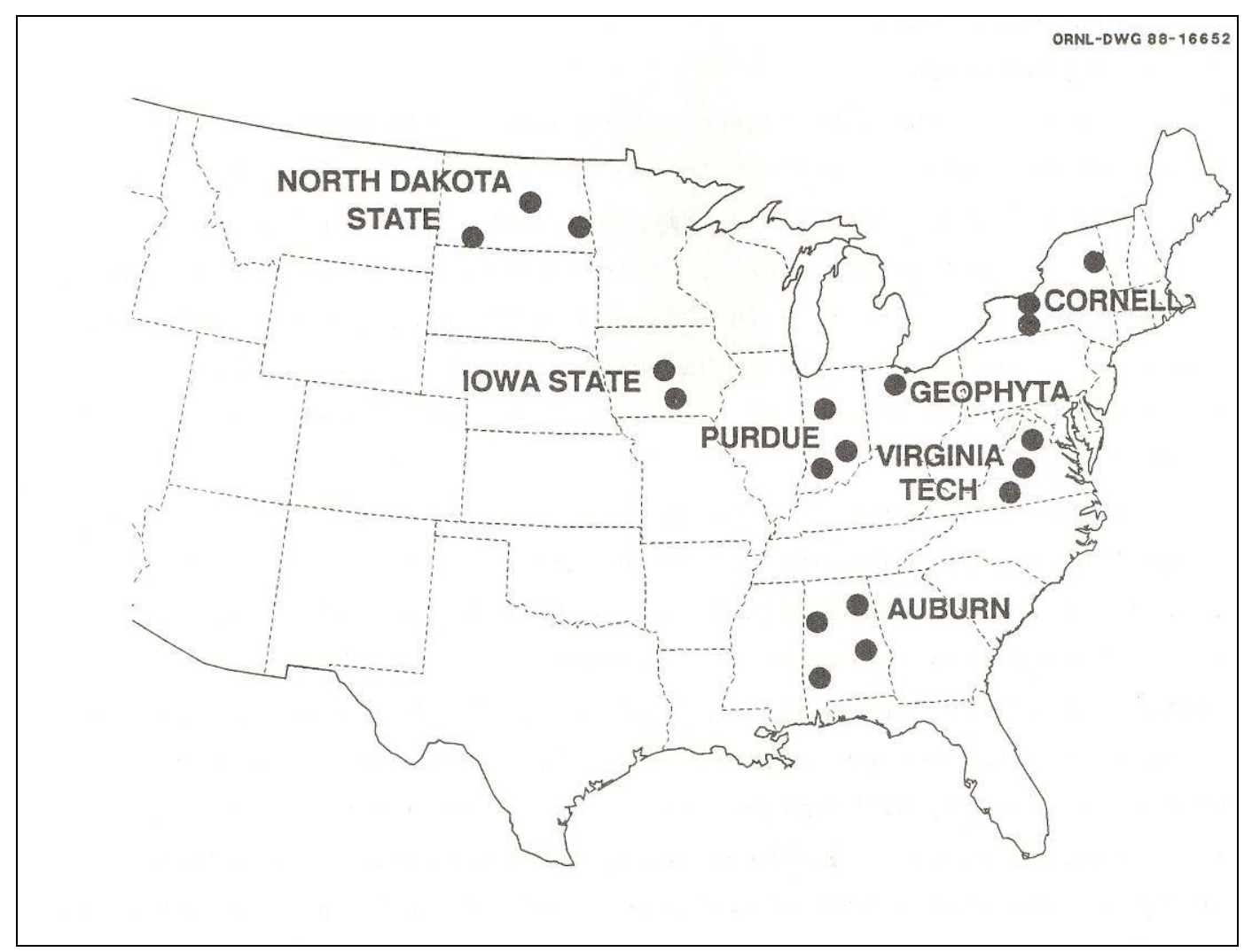

Figure 1. Location of herbaceous crop field testing sites

The proposals included the testing of warm season, cool season, and leguminous perennials in each area as well as several annuals. Annuals were also planted for comparison purposes. Table 1 shows the full range of species tested by each institution involved in herbaceous screening research. Table 2 provides information about each of the test sites used for the screening trials in the southeast, Midwest/Lake, and Great Plains regions respectively. 


\begin{tabular}{|c|c|c|c|c|c|c|c|}
\hline \multirow[t]{2}{*}{ Species } & \multicolumn{7}{|c|}{ Institution and year of project start } \\
\hline & VA Tech & Auburn & Geophyta & Cornell & Purdue & ISU $^{1}$ & $\mathrm{NDSU}^{2}$ \\
\hline & 1985 & 1985 & 1985 & 1985 & 1985 & 1988 & 1988 \\
\hline \multicolumn{8}{|l|}{ Grasses: Annual } \\
\hline Corn $(w)$ & & $\mathbf{x}$ & $\mathbf{x}$ & & $\mathbf{x}$ & $\mathbf{x}$ & \\
\hline Pearl millet $(w)$ & & $\mathrm{X}^{4}$ & & & & & \\
\hline Foxtail millet $(w)$ & & & & & & & $\mathbf{x}$ \\
\hline Rye (c) & & $\mathrm{X}^{3}$ & $\mathrm{X}^{3}$ & & $\mathrm{X}^{3}$ & $x^{3}$ & \\
\hline Sorghum, Forage $(w)$ & & & $\mathbf{X}$ & & & $\mathbf{x}$ & \\
\hline Sorghum, Sweet (w) & & $x^{4}$ & & & $\mathbf{x}$ & $\mathbf{x}$ & \\
\hline Sorghum $\mathrm{x}$ sudangrass $(\mathrm{w})$ & $\mathbf{x}$ & & & & $\mathbf{x}$ & $\mathbf{x}$ & \\
\hline Sudangrass (w) & & & & $\mathbf{x}$ & & & \\
\hline \multicolumn{8}{|l|}{ Grasses: Perennial } \\
\hline Bahiagrass (w) & & $\mathbf{x}$ & & & & & \\
\hline Bermudagrass (w) & & $\mathrm{x}^{4}$ & & & & & \\
\hline Big bluestem $(w)$ & & & & & $\mathbf{x}$ & $\mathbf{X}$ & \\
\hline Crested wheatgrass (c) & & & & & & & $\mathbf{x}$ \\
\hline CRP mixture of grasses $(\mathrm{c} / \mathrm{w})$ & & & & & & & $\mathbf{x}$ \\
\hline Eastern gamagrass $(\mathrm{c})$ & & & & $\mathbf{x}$ & & & \\
\hline Energy Cane $(\mathrm{w})$ & & $\mathbf{x}$ & & & & & \\
\hline Intermediate wheatgrass (c) & & & & & & & $\mathbf{x}$ \\
\hline Johnsongrass (w) & & $x^{4}$ & & & & & \\
\hline \multicolumn{8}{|l|}{ Napiergrass (w) } \\
\hline Redtop (c) & & & & $\mathbf{x}$ & & & \\
\hline Reed canarygrass (c) & & & $\mathbf{x}$ & $\mathrm{x}$ & $x^{5}$ & $\mathbf{x}$ & $\mathbf{x}$ \\
\hline Smooth bromegrass (c) & & & & & & & $\mathbf{x}$ \\
\hline Switchgrass (w) & $\bar{x}$ & $\bar{x}$ & $\mathbf{x}$ & $\mathbf{x}$ & $\mathbf{x}$ & $\bar{x}$ & $\mathrm{X}$ \\
\hline Tall Fescue (c) & $\mathbf{x}$ & $\mathrm{x}$ & $\mathbf{x}$ & & $x^{5}$ & & \\
\hline Timothy (c)/redtop (c)/ clover & & & $\bar{x}$ & $\bar{x}$ & & & \\
\hline Weeping lovegrass $(\mathrm{w})$ & $\mathbf{x}$ & & & & $\mathbf{x}$ & & \\
\hline Wheatgrass mixture (c) & & & & & & & $\mathbf{x}$ \\
\hline \multicolumn{8}{|l|}{ Legumes: Annual } \\
\hline Soybeans & & & & & & $\mathbf{x}$ & \\
\hline \multicolumn{8}{|l|}{ Legumes: Perennial } \\
\hline Alfalfa & & & $\mathbf{x}$ & $x^{6}$ & $\mathbf{x}$ & $X^{7}$ & $x^{6}$ \\
\hline Birdsfoot trefoil & $\mathbf{x}$ & & $\mathbf{x}$ & & $\mathbf{x}$ & $\mathbf{x}$ & \\
\hline Crownvetch & $\mathbf{x}$ & & & & & & \\
\hline Flatpea & $\mathbf{x}$ & & & $\mathbf{x}$ & & & \\
\hline Serecia lespedeza & $\mathbf{x}$ & $\bar{x}$ & & & $\mathbf{x}$ & & \\
\hline Sweet clover & & & & $\mathbf{x}$ & & & $\mathbf{x}$ \\
\hline \multicolumn{8}{|l|}{ Other } \\
\hline Forage brassica & & & & $\mathbf{X}$ & & & \\
\hline Kale & & & & $\mathbf{x}$ & & & \\
\hline $\begin{array}{l}\text { Meadow (mixed grasses \& } \\
\text { legumes) }\end{array}$ & & & & $\mathbf{x}$ & & & \\
\hline $\begin{array}{l}\text { Note: The grasses are designated } \\
{ }^{1} \text { ISU = Iowa State University } \\
{ }^{2} \text { NDSU = North Dakota State Un } \\
{ }^{3} \text { Rye was always interseeded am } \\
\text { sorghums } \\
{ }^{4} \text { These crops were frequently the } \\
{ }^{5} \text { Reed canary grass and tall fescu } \\
{ }^{6} \text { Alfalfa was intercropped with b } \\
7\end{array}$ & $\begin{array}{l}\text { ither cool s } \\
\text { rsity } \\
\text { other speci } \\
\text { se species ir } \\
\text { ere grown } \\
\text { egrass at b } \\
\text { hum and sol }\end{array}$ & $\begin{array}{l}\text { ason }(\mathrm{c}) \text { or } \\
\text { s or as the } \\
\text { a double-c } \\
\text { one and in } \\
\text { h Cornell } \\
\text { hum } x \text { sud }\end{array}$ & $\begin{array}{l}\text { warm season } \\
\text { ool season } \mathrm{s} \text { 1 } \\
\text { opping or int } \\
\text { erseeded witl } \\
\text { dd NDSU, ar } \\
\text { ngrass }\end{array}$ & $\begin{array}{l}\text { (w) crops. } \\
\text { ecies in a } \\
\text { rcropping } \\
\text { sorghum } \\
\text { d also grov }\end{array}$ & $\begin{array}{l}\text { ble crop s } \\
\text { tems } \\
\text { alone at } \mathrm{N}\end{array}$ & $\begin{array}{l}\text { tem - mos } \\
\text { SU }\end{array}$ & ften with \\
\hline
\end{tabular}


Table 2. Descriptions of herbaceous crop screening test sites

\begin{tabular}{|c|c|c|c|c|}
\hline Location name & Soil type & Slope and class & Quality & Limitation(s) \\
\hline $\begin{array}{l}\text { Virginia Tech } \\
\text { (Virginia) }\end{array}$ & \multicolumn{4}{|c|}{$\begin{array}{l}3 \text { locations, soils representative of the piedmont region of the southeastern U.S., } \\
\text { sloping, southwest facing (hot and dry) }{ }^{(11,12)}\end{array}$} \\
\hline Lunenberg County & $\begin{array}{l}\text { Appling } \\
\text { sandy loam }\end{array}$ & $6 \& 7 \%$ slopes & $\begin{array}{l}\text { Poor, } \\
\text { Coarse textured }\end{array}$ & $\begin{array}{l}\text { Strongly acidic } \\
\text { highly erosive } \\
\text { low nutrient }\end{array}$ \\
\hline $\begin{array}{l}\text { Amelia County } \\
\text { NE facing slopes } \\
3 \text { sites }\end{array}$ & Cecil & $8 \& 9 \%$ slopes & $\begin{array}{l}\text { Poor, } \\
\text { Long-term erosion }\end{array}$ & $\begin{array}{l}\text { Acidic } \\
\text { highly erosive }\end{array}$ \\
\hline Orange County & Davison & $9 \& 10 \%$ slopes & Not quite as poor & $\begin{array}{l}\text { Strongly acidic, } \\
\text { highly erosive }\end{array}$ \\
\hline Auburn (Alabama) & \multicolumn{4}{|c|}{$\begin{array}{l}4 \text { sites represent the physiographic provinces of AL, "all soils good for crop } \\
\text { production if erosion minimized on slopes" (13) }\end{array}$} \\
\hline $\begin{array}{l}\text { Camden - Lower } \\
\text { coastal plain }\end{array}$ & $\begin{array}{l}\text { Mabis } \\
\text { fine sandy loam }\end{array}$ & NA & NA & $\begin{array}{l}\text { Fragipan and } \\
\text { acidic subsoil, } \\
\text { erosive }\end{array}$ \\
\hline $\begin{array}{l}\text { Winfield - Upper } \\
\text { coastal plain }\end{array}$ & $\begin{array}{l}\text { Savannah } \\
\text { loam }\end{array}$ & $2-10 \%$ slopes & NA & $\begin{array}{l}\text { Fragipan and } \\
\text { erosive }\end{array}$ \\
\hline Camp Hill- Piedmont & $\begin{array}{l}\text { Cecil } \\
\text { sandy loam }\end{array}$ & NA & NA & Acidic, erosive \\
\hline $\begin{array}{l}\text { Crossville- Sand } \\
\text { Mountain site }\end{array}$ & $\begin{array}{l}\text { Hartsells } \\
\text { fine sandy loam }\end{array}$ & $2-5 \%$ slopes & NA & Erosive on slopes \\
\hline Geophyta (Ohio) & \multicolumn{4}{|c|}{3 sites in northeast part of state with varying levels of wetness compared ${ }^{(14)}$} \\
\hline Site 1 & $\begin{array}{l}\text { Toledo or Lucus } \\
\text { silty clay }\end{array}$ & $0-2 \%$ & $\begin{array}{l}\text { Adequate soil pH } \\
\text { and high fertility }\end{array}$ & Occasional wetness \\
\hline Site 2 & $\begin{array}{l}\text { Toledo or Lucus } \\
\text { silty clay }\end{array}$ & $2-6 \%$ & $\begin{array}{l}\text { Adequate soil } \mathrm{pH} \\
\text { and fertility }\end{array}$ & $\begin{array}{l}\text { Moderate wetness, } \\
\text { no tile }\end{array}$ \\
\hline Site 3 & $\begin{array}{l}\text { Toledo or Lucus } \\
\text { silty clay }\end{array}$ & $0-2 \%$ & $\begin{array}{l}\text { Low soil } \mathrm{pH} \text {, low } \\
\text { available } \mathrm{P}\end{array}$ & $\begin{array}{l}\text { Frequent wetness, } \\
\text { no tile }\end{array}$ \\
\hline $\begin{array}{l}\text { Cornell } \\
\text { (New York) }\end{array}$ & \multicolumn{4}{|c|}{$\begin{array}{l}8 \text { sites with } 6 \text { soil series, each a unique combination of use and production } \\
\text { limitations }{ }^{(15)}\end{array}$} \\
\hline $\begin{array}{l}\text { Poole farm Geneva, } \\
\text { NY }\end{array}$ & $\begin{array}{l}\text { Honeoye, } \\
\text { silt loam }\end{array}$ & $10 \%$ slope & Excellent & Erosion \\
\hline $\begin{array}{l}\text { Aurora, NY Finger } \\
\text { Lakes area }\end{array}$ & $\begin{array}{l}\text { Kendia, } \\
\text { silt loam }\end{array}$ & Minimal & Prime & None \\
\hline $\begin{array}{l}\text { Mt Pleasant farm, } \\
\text { Freeville, NY } \\
\text { Mid-south NY }\end{array}$ & $\begin{array}{l}\text { Mardin, } \\
\text { acid glacial till }\end{array}$ & Minimal & Marginal & $\begin{array}{l}\text { Strongly acid, } \\
\text { low fertility, } \\
\text { fragipan }\end{array}$ \\
\hline $\begin{array}{l}\text { Halme farm, Ithaca, } \\
\text { NY Finger lakes }\end{array}$ & $\begin{array}{l}\text { Erie soil, } \\
\text { fine silt }\end{array}$ & Minimal & Marginal & $\begin{array}{l}\text { Wetness, acidity, } \\
\text { stones, low- } \\
\text { fertility }\end{array}$ \\
\hline $\begin{array}{l}\text { Caldwell farm, Ithaca, } \\
\text { NY }\end{array}$ & $\begin{array}{l}\text { Collamar, } \\
\text { fine textured }\end{array}$ & Less slope & Marginal & Erodible \\
\hline $\begin{array}{l}\text { Caldwell farm, Ithaca, } \\
\text { NY }\end{array}$ & $\begin{array}{l}\text { Collamar, } \\
\text { fine textured }\end{array}$ & More slope & Marginal & Erodible \\
\hline $\begin{array}{l}\text { Willsboro farm } \\
\text { Northeast, NY }\end{array}$ & $\begin{array}{l}\text { Rhinebeck, } \\
\text { fine texture clay }\end{array}$ & Minimal & Marginal & Wetness \\
\hline $\begin{array}{l}\text { Willsboro farm } \\
\text { Northeast, NY }\end{array}$ & $\begin{array}{l}\text { Mardin, } \\
\text { fine texture clay }\end{array}$ & Minimal & Marginal & Wetness \\
\hline Purdue (Indiana) & \multicolumn{4}{|c|}{3 regions of state, range of soil qualities and slope effects compared ${ }^{(16)}$} \\
\hline Purdue Agronomy & Chalmers & $0-2 \%$ slope & Good & Minimal \\
\hline
\end{tabular}




\begin{tabular}{|c|c|c|c|c|}
\hline Farm & silty clay loam & & & \\
\hline $\begin{array}{l}\text { SIPAC (Southern } \\
\text { Purdue Agricultural } \\
\text { Center) }\end{array}$ & $\begin{array}{l}\text { Zanesville } \\
\text { silt loam }\end{array}$ & $8-12 \%$ slope & $\begin{array}{l}\text { Marginal, Previous } \\
\text { crop tall fescue }\end{array}$ & $\begin{array}{l}\text { Fragipan, erosion, } \\
\text { droughty }\end{array}$ \\
\hline $\begin{array}{l}\text { SEPAC (Southeastern } \\
\text { Purdue Agricultural } \\
\text { Center) }\end{array}$ & $\begin{array}{l}\text { Cincinnati } \\
\text { silt loam }\end{array}$ & $8-10 \%$ slope & $\begin{array}{l}\text { Marginal, Previous } \\
\text { crop tilled corn }\end{array}$ & $\begin{array}{l}\text { Erosion, fragipan, } \\
\text { poor drainage }\end{array}$ \\
\hline $\begin{array}{l}\text { T-FLAT } \\
\text { (West central } \\
\text { Throckmorton Purdue } \\
\text { Agricultural Center) }\end{array}$ & $\begin{array}{l}\text { Slidell } \\
\text { silt loam }\end{array}$ & $0-2 \%$ slope & $\begin{array}{l}\text { Excellent, Previous } \\
\text { crop tilled corn }\end{array}$ & Minimal \\
\hline $\begin{array}{l}\text { T-SLOPE } \\
\text { (West central } \\
\text { Throckmorton Purdue } \\
\text { Agricultural Center) }\end{array}$ & $\begin{array}{l}\text { Slidell } \\
\text { silt loam }\end{array}$ & 6-8\% slope & $\begin{array}{l}\text { Excellent, Previous } \\
\text { crop tilled corn }\end{array}$ & Erosion \\
\hline $\begin{array}{l}\text { Iowa State } \\
\text { (Iowa) }\end{array}$ & \multicolumn{4}{|c|}{2 regions of state plus good and marginal soils compared ${ }^{(17)}$} \\
\hline Ames -central Iowa & $\begin{array}{l}\text { Harps soil } \\
\text { Silty clay loam }\end{array}$ & $\begin{array}{l}0-1 \% \text { slope } \\
\text { Class I } \\
\text { SOM }=7 \%\end{array}$ & $\begin{array}{l}\text { Highly productive } \\
\text { Corn/soybean/oat } \\
\text { rotation in } 1987\end{array}$ & $\begin{array}{l}\mathrm{pH} \text { of } 8.0 \\
2 \mathrm{~m} \text { rooting depth }\end{array}$ \\
\hline $\begin{array}{l}\text { Chariton - southern } \\
\text { Iowa }\end{array}$ & $\begin{array}{l}\text { Clarinda, Cearfield } \\
\text { and Grundy soils }\end{array}$ & $\begin{array}{l}2-7 \% \text { slope } \\
\text { Class III } \\
\text { SOM } 4 \%\end{array}$ & $\begin{array}{l}\text { Lower productivity } \\
\text { soil } \\
\text { Conventional red } \\
\text { clover prior use } \\
\end{array}$ & $\begin{array}{l}\text { Erosive } \\
\text { Droughty } \\
\text { pH of } 6.8\end{array}$ \\
\hline $\begin{array}{l}\text { North Dakota State } \\
\text { Univ (ND) }\end{array}$ & \multicolumn{4}{|c|}{$\begin{array}{l}5 \text { dryland sites and } 1 \text { irrigated site representing } 3 \text { major soil areas in North } \\
\text { Dakota }^{(18)}\end{array}$} \\
\hline $\begin{array}{l}\text { (1) Prosper } \\
\text { Red River Valley }\end{array}$ & $\begin{array}{l}\text { Gardena } \\
\text { Silt loam }\end{array}$ & level & $\begin{array}{l}\text { Productive, } \\
\text { Lacustrine sediments }\end{array}$ & Moderate rainfall \\
\hline $\begin{array}{l}\text { (2) Hettinger } \\
\text { Missouri Plateau }\end{array}$ & $\begin{array}{l}\text { Shambo } \\
\text { Silt loam }\end{array}$ & $0-2 \%$ & Productive, Alluvium & Very low rainfall \\
\hline $\begin{array}{l}\text { (3) Glenfield a } \\
\text { Drift Prairie }\end{array}$ & $\begin{array}{l}\text { Barnes loam to } \\
\text { Siva loam }\end{array}$ & NA & $\begin{array}{l}\text { Productive, Glacial } \\
\text { till }\end{array}$ & Low rainfall \\
\hline $\begin{array}{l}\text { (4) Leonard } \\
\text { Red River Valley }\end{array}$ & $\begin{array}{l}\text { Hecla } \\
\text { Loamy fine sand }\end{array}$ & Nearly level & Marginal,CRP land & $\begin{array}{l}\text { Wind erosion } \\
\text { Moderate rainfall }\end{array}$ \\
\hline $\begin{array}{l}\text { (5) Glenfield b } \\
\text { Drift Prairie }\end{array}$ & Buse loam & Crests of hills & $\begin{array}{l}\text { Marginal, CRP land, } \\
\text { Glacial till }\end{array}$ & Low rainfall \\
\hline (6) Carrington & Emrick loam & level & $\begin{array}{l}\text { Productive with } \\
\text { irrigation; glacial till }\end{array}$ & $\begin{array}{l}\text { Requires } \\
\text { irrigation }\end{array}$ \\
\hline
\end{tabular}

\subsection{SCREENING TRIAL RESULTS AND RECOMMENDATIONS}

Yields of each crop were quite variable between investigators, sites, and years representing not only site and climate variations but also a lack of experience in growing some of the perennial grasses as crops. Yield results derived from tables in the final reports of the herbaceous crop screening trials are either included in the descriptions below (if short) or provided in the appendixes (if long). Because climate conditions had a large effect on establishment success and yield results, particular notice is made of the principal investigators comments about climate conditions during their trials. When final reports included recommendations for further research, an effort is made to capture those recommendations in the discussion below about each of the herbaceous crop screening projects. An eighth project, a study of the potential of successional vegetation to be a bioenergy feedstock, is also described.

\subsubsection{Virginia Tech - Virginia}


Parrish et al. reported in $1990^{(11)}$ that initial screening results were heavily affected by the severe drought that occurred during the first 4 weeks after the initial planting in 1985. Warm season perennial grasses survived but cool season grasses had to be reseeded several times in 1986 and grew poorly in 1987. These were both years with a moisture deficit. Rainfall was more nearly adequate in 1988 and 1989, resulting in the cool season grasses and legumes showing a good response to the rainfall. However, across the 4 post-establishment years (86-89) with 2 years of drought and 2 years of average or above average rain, switchgrass clearly outperformed all the other species being tested including sorghum $\mathrm{x}$ sudangrass on 3 marginal agricultural soils (Table 3 ). Yields of sorghum $\mathrm{x}$ sudangrass were 3 times that of switchgrass in the establishment year (1985) and slightly higher in 1986, but through the rest of the study sorghum x sudangrass yields trended downward while switchgrass yields continued to increase. On one site sorghum $\mathrm{x}$ sudangrass experienced near or complete failure in 2 years. Averaged over sites and years, the cool season grasses achieved an average of between 5 and $6 \mathrm{Mg} \mathrm{ha}^{-1} \mathrm{yr}^{-1}$. Switchgrass averaged $10.6 \mathrm{Mg} \mathrm{ha}^{-1} \mathrm{yr}^{-1}$, and weeping lovegrass, also a warm season grass, averaged $9.3 \mathrm{Mg} \mathrm{ha}^{-1} \mathrm{yr}^{-1}$. These two species were recommended for further study by the Virginia Tech investigators. Following their own recommendations, Virginia Tech researchers initiated management studies focusing on switchgrass and weeping lovegrass in 1988. ${ }^{(12)}$ While both species continued to show promise as relatively low input energy crops, yields and stand vigor declined in the weeping lovegrass trials after 4 years, thus switchgrass seemed to be the most promising species. More detailed studies on switchgrass by Virginia Tech demonstrated that no-till management could be successfully used to establish perennial grasses and to reduce soil loss on sloping marginal land and that the deep rooting depth of switchgrass was a contributor to its productivity and to soil carbon enhancement.

Table 3. Mean annual biomass yield averaged across 12 sites for eight herbaceous biomass species on three soil types in the Piedmont of Virginia.

\begin{tabular}{|c|c|c|c|c|c|}
\hline Species & 1986 & 1987 & 1988 & 1989 & 4-Year Avg \\
\hline & 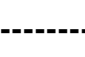 & ----. & $---M g$ & & ------------. \\
\hline \multicolumn{6}{|l|}{ Warm-Season } \\
\hline Sorghum-sudan & 8.6 & 7.9 & 9.5 & 4.7 & 7.7 \\
\hline Lovegrass & 8.7 & 8.9 & 11.2 & 8.2 & 9.3 \\
\hline Switchgrass & 7.8 & 10.8 & 11.9 & 11.8 & 10.6 \\
\hline Sericea & 3.1 & 6.4 & 7.7 & 7.4 & 6.1 \\
\hline \multicolumn{6}{|l|}{ Cool-Season } \\
\hline Tall fescue & 1.9 & 7.1 & 5.2 & 5.9 & 5.0 \\
\hline Crownvetch & 0.9 & 4.1 & 8.2 & 9.7 & 5.7 \\
\hline Trefoil & 1.0 & 6.5 & 6.0 & 7.4 & 5.2 \\
\hline Flatpea & 1.6 & 3.5 & 4.9 & 10.7 & 5.2 \\
\hline
\end{tabular}

Note: Table reproduced from Parish et al. ${ }^{(11)}$

\subsubsection{Auburn University - Alabama}


The rainfall data reported by Bransby et al. ${ }^{(13)}$ showed that across 4 physiographic regions in Alabama, growing season rainfall was near normal in the first two years (1985 and 1986), substantially below normal in 1987, and normal in 1988 and above normal in 1989 . Yields of annual species were some to much higher than perennials in years of moderate to good rainfall but lower than perennials in lower rainfall years (Appendix A). For example, sweet sorghum yields varied from a mean of $17.93 \mathrm{Mg}$ $\mathrm{ha}^{-1} \mathrm{yr}^{-1}$ in 1985 to a low of $3.8 \mathrm{ha}^{-1} \mathrm{yr}^{-1}$ in 1987. Although switchgrass yields were low in the establishment year $\left(2.44 \mathrm{Mg} \mathrm{ha}^{-1}\right)$, yields increased over the next 4 years showing relatively little response to precipitation. The higher yield variability plus higher production costs of the annuals lead to the recommendation to drop annuals and to focus on perennials for future crop development.

Johnsongrass, a warm season perennial "weed", performed better than other perennials in the first two seasons. This was attributed to its larger seed size but johnsongrass growth decreased over time and was correlated with an increase in disease and soil compaction. All other warm season perennials, switchgrass, bermudagrass, and sericea lespedeza established more slowly but continued to increase yields over the 5 years achieving an average of $9 \mathrm{Mg} \mathrm{ha}^{-1} \mathrm{yr}^{-1}$. The success and reliability of the perennials encouraged the Auburn University investigators to add evaluations of sub-tropical tall grasses in 1987 and a variety trial of switchgrass to the project in 1988. The tall grasses quickly achieved very high annual yields ranging from 12.2 up to $32.4 \mathrm{Mg} \mathrm{ha}^{-1}$ with energy cane showing the highest yields (16.5 to $32.4 \mathrm{Mg} \mathrm{ha}^{-1}$ ). The switchgrass established quickly in the normal rainfall year of 1988 and by 1989 the variety, Alamo, had achieved yields of $17.5 \mathrm{Mg} \mathrm{ha}^{-1}$, double that of the original test variety, Cave-in-Rock. The final report (13) recommended that further research should focus on only a few perennial species such as switchgrass, lespedeza, and energy cane. The advantages of switchgrass were described as: (a) it can be established from seed, (b) it can be harvested and stored as hay, (c) it can be used for both biomass and forage, (d) it has relatively low lignin content, and (e) the high genetic variability with the species provides excellent opportunities for improvement by selection and breeding. Bransby's discovery of the high yield potential of the switchgrass variety, Alamo, was a major factor in the acceptance of switchgrass as a suitable model species. ${ }^{(2)}$

\subsubsection{Geophyta - Ohio}

Wright reported in $1990^{(14)}$ that planting efforts in 1985 and 1986 were affected by a combination of heavy rains initially followed by no or low amounts of rain. Wetness was a problem for only long enough to negatively affecting planting. Rainfall was not mentioned for 1987 and 1989, thus was assumed to be normal. 1988 was described as extremely dry. The investigator identified the most promising energy crops of the 10 evaluated in a wet area of northern Ohio as forage sorghum, rye cropped with sorghum x sudangrass, and reed canarygrass. However an investigation of the data, (Appendix C) shows that switchgrass showed the next highest average yields and demonstrated greater reliability. The switchgrass did establish at all three sites (which the reed canarygrass did not) and the switchgrass yields $\left(4.1-9.0 \mathrm{Mg} \mathrm{ha}^{-1}\right)$ were only a little less than those of reed canarygrass (5.1-10.3 $\mathrm{Mg} \mathrm{ha}^{-1}$ ) on the two sites where both crops could be compared. Both of these grasses had their best yields in the $4^{\text {th }}$ year (1989) when forage sorghum yields were very poor. Rye cropped with sorghum x sudangrass (yields ranging from 7.9 to $23 \mathrm{Mg} \mathrm{ha}^{-1}$ ) produced more reliable yields than forage sorghum alone, which had establishment failures in 1988 and 1989. The investigator did note that the cool season grasses (including reed canarygrass) always had green leaves (higher nutrient levels) at fall harvest, while switchgrass and sorghum had the lowest nutrient concentrations at fall harvest (suggesting greater potential for sustainable production).

An interesting side observation of the study was that in control plots with no weed control it was noted that weed growth provided the majority of the biomass and weed-only plots provided respectable yields. Weed plots fertilized at the same level as the double crop of rye and sorghum $\mathrm{x}$ 
sudangrass produced yields in the range of 3.5 to $4.2 \mathrm{Mg} \mathrm{ha}^{-1}$. While the rye/sorghum $\mathrm{x}$ sudangrass combination produced much higher yields, the investigator noted that compared to the complete establishment failures that occurred with some crops in some years the idea of fertilizing abandoned fields merited further consideration. ${ }^{(14)}$

\subsubsection{Cornell University - New York}

Precipitation patterns in the Cornell University trials varied among the seven locations where crops were evaluated ${ }^{(15,19)}$ but followed a similar pattern to that experienced at other screening trials. The years of 1985 and 1988 experienced somewhat to seriously below normal precipitation, 1986 was closer to normal, 1987 had above and below normal precipitation depending on location, and 1989 was generally normal or above for all sites. Eight energy crop species plus a "meadow" trial were evaluated. Yield results were relatively similar for most of the species tested (in the range of 4 to 10 $\mathrm{Mg} \mathrm{ha}^{-1}$ ) during the 3 best years (out of 5) of yield results (Table 4). Evaluation of the potential for energy crops in the region was based on modeling studies as well as on field trials. The investigators concluded that "careful management of better-drained" soil resources and proper selection of plant species grown for biomass will provide an annual yield of dry matter in the Great Lakes Region on the order of 10-12 $\mathrm{Mg} \mathrm{ha}^{-1}$. The recommendations for the species with highest potential as a bioenergy crop varied for well drained versus the poorly drained soils.

On moderately to well drained soils, the legume mixtures, alfalfa-bromegrass and timothy-redtop-red clover were considered to be the most promising. ${ }^{(19)}$ Switchgrass was identified as showing promise for well-drained sites, but the establishment problems and weed competition experienced in the trials were a concern. The investigators did suggest that the variety used in the trials (Cave-in-Rock) was possibly not the best choice for the area and that more work on switchgrass was merited for the Great Lakes Region. On poorly drained soils, reed canarygrass out yielded all other species with average yields of about $7 \mathrm{Mg} \mathrm{ha}^{-1} \mathrm{yr}^{-1}$. It was recommended as a high potential species for poorly drained soils under a one-cut harvest system timed to coincide with drier soil conditions. The relatively low-input meadow plots were also observed to have potential for wet soils where tillage is not possible, with an average yield potential of 5 to $7 \mathrm{Mg} \mathrm{ha}^{-1} \mathrm{yr}^{-1}$ with one or two harvests/year.

Table 4. Average yields of the three highest-yield consecutive years during the first 5 years of production for perennial biomass crops grown in the eastern Great lakes Region

\begin{tabular}{|c|c|c|c|c|c|c|c|}
\hline & \multicolumn{3}{|c|}{ Moderately to well drained sites } & \multicolumn{4}{|c|}{ Poorly drained sites } \\
\hline & Collamer & $\begin{array}{l}\begin{array}{l}\text { Collamer } \\
\text { (eroded) }\end{array} \\
\end{array}$ & $\begin{array}{l}\text { Honeoye } \\
\text { (eroded) }\end{array}$ & Mardin & Madalin & Rhinebeck & Erie \\
\hline $\begin{array}{l}\text { Species or } \\
\text { mixture }\end{array}$ & -------. & & -Mg & & & & ----- \\
\hline $\begin{array}{l}\text { Alfalfa/ smooth } \\
\text { bromegrass }\end{array}$ & $8.88 \mathrm{ab}$ & $10.01 \mathrm{a}$ & $11.30 \mathrm{a}$ & & & & \\
\hline $\begin{array}{l}\text { Eastern } \\
\text { gamagrass }\end{array}$ & & & & & & & $6.07 b$ \\
\hline Flatpea & $9.48 \mathrm{a}$ & $8.66 \mathrm{~b}$ & $9.49 \mathrm{~b}$ & $7.45 \mathrm{a}$ & & & \\
\hline $\begin{array}{l}\text { Naturalized } \\
\text { meadow }\end{array}$ & & & & & $5.53 \mathrm{ab}$ & $5.25 \mathrm{ab}$ & $5.61 \mathrm{~b}$ \\
\hline Reed canarygrass & & & & & $7.13 a$ & $6.80 \mathrm{a}$ & $9.02 \mathrm{a}$ \\
\hline Switchgrass & $8.76 \mathrm{ab}$ & $8.53 \mathrm{~b}$ & $5.79 \mathrm{~d}$ & $4.36 \mathrm{~b}$ & $4.85 \mathrm{~b}$ & $4.17 \mathrm{~b}$ & \\
\hline Timothy mixture & $8.15 \mathrm{~b}$ & $10.14 \mathrm{a}$ & $7.04 \mathrm{c}$ & $7.35 \mathrm{a}$ & $5.62 \mathrm{ab}$ & $5.16 \mathrm{ab}$ & $5.83 \mathrm{~b}$ \\
\hline
\end{tabular}

Note: means within a column followed by the same letter are not significantly different $(\mathrm{P}>0.05)$.

\subsubsection{Purdue University - Indiana}

Cherney et al. reported in $1990^{(16)}$ that climate included both normal and droughty conditions during 
the years of 1985-1989 at all four sites used in testing, but no details were provided. The study evaluated 12 herbaceous crop species with some being considered both alone and as intercrop species. Of the perennial species investigated, switchgrass was deemed to have the greatest biomass potential yielding up to $16 \mathrm{Mg} \mathrm{ha}^{-1}$ in one season with two cuttings. When grown with minimal fertilizer inputs and one harvest per year, switchgrass was superior in yield to tall fescue, reed canarygrass, alfalfa, birdsfoot trefoil, weeping lovegrass, big bluestem, and sericea lespedeza. Annual yields of the switchgrass (Cave-in-Rock) were in the range of $7-16 \mathrm{Mg} \mathrm{ha}^{-1}$ with the lowest yield occurring in the drought year of 1988. Comparison of yields among crops in 1988 (a drought year) highlights the relative similarity of yields of several perennial grasses across good and poor sites in comparison with alfalfa and sorghums (Table 5). Advantages of switchgrass were described to be its minimum fertilizer input requirements, its persistence, and its effectiveness in reducing soil erosion.

Establishment problems did occur with switchgrass at the poorest site. Response of switchgrass to fertilizer varied from year to year, but the greatest response was always between 0 and $50 \mathrm{~kg} \mathrm{~N} \mathrm{ha}^{-1}$ with higher levels producing some to little additional response (Appendix D).

Of the annual species evaluated, sweet sorghum produced higher yields than sorghum-sundangrass and corn, attaining up to $32 \mathrm{Mg} \mathrm{ha}^{-1}$ with one harvest in 1989. Several varieties of sorghum were tested with some attaining high yields on some sites even during the extreme drought year of 1988 (Table 5). Average yields across the 4 sites for sweet sorghum were 22.2, 19.1, 15.8 and $8.9 \mathrm{Mg} \mathrm{ha}{ }^{-1}$, respectively for the years $1985,1986,1987$, and 1988. The large decline in 1988 was due to very low yields at 2 of the 4 testing sites. But additionally Cherney et al. ${ }^{(16)}$ expressed concern that the decline in yields observed over the 4 year period was related to continuous sorghum culture as well as droughty conditions. Sorghum double cropped with rye was a very productive management option but required more inputs than switchgrass. Interseeding sorghum into perennial grasses was not a viable option due to its great dependence on environmental variables. However, no-till culture of sorghums did appear to be viable. Sweet sorghum yield response to fertilizer varied with year (Appendix D) .

A separate analysis of the Purdue University screening results by Dobbins et al. ${ }^{(20)}$ considered the economic potential of the crops in Indiana. The analysis indicated that biomass feedstock production could be economically viable on marginal land in the Midwest and could compete favorably for land with traditional crops. Sorghum-sudangrass, sweet sorghum, reed canarygrass, and switchgrass were all identified as promising crops for Midwest production. Based on production costs alone, the most promising crops appeared to be switchgrass and sweet sorghum. The results of a whole farm analysis suggested that reed canarygrass, switchgrass, and sweet sorghum were the alternatives that provided the best returns for the land, labor, and machinery resources available.

\subsubsection{Iowa State University - Iowa}

Anderson et al. ${ }^{(17)}$ reported in 1994 that in the first two years of field trials rainfall was either significantly (1988) or somewhat (1989) below normal early in the season. During the rest of the screening period through 1992 rainfall was either significantly above normal (1990) or relatively normal. At the Chariton (a marginal site), reed canarygrass totally failed to establish in 1988, big bluestem established very poorly, and switchgrass and alfalfa had very low yields in the first year, though all perennials were re-established in 1989. However, several sorghum varieties and even corn did establish and produce acceptable yields at Chariton even in 1988. All crops successfully established at the Ames site. Yield results from both sites are summarized in Appendix E. The agronomic report from Iowa State University ${ }^{(17)}$ provided an excellent summary of the screening

Table 5. Yields of herbaceous biomass crops grown at four sites in Indiana during the drought year of 1988. ${ }^{\mathrm{a}}$

\begin{tabular}{|c|c|c|c|c|}
\hline Sit & T-Flat & T-Slope & SEPAC & GDU \\
\hline
\end{tabular}




\begin{tabular}{|c|c|c|c|c|}
\hline & $\begin{array}{l}\text { (excellent } \\
\text { cropland) }\end{array}$ & $\begin{array}{l}\text { (excellent } \\
\text { cropland) }\end{array}$ & $\begin{array}{l}\text { (marginal } \\
\text { cropland) }\end{array}$ & $\begin{array}{l}\text { (marginal } \\
\text { cropland) }\end{array}$ \\
\hline Species & ----------- & ------------- & & ---------- \\
\hline Alfalfa & 17.36 & 13.28 & 9.98 & 1.62 \\
\hline Birdsfoot trefoil & 8.03 & 6.31 & 5.88 & 5.25 \\
\hline Tall fescue & 6.22 & 3.52 & 4.28 & 6.73 \\
\hline Reed canarygrass & 5.99 & 4.10 & 5.12 & 6.27 \\
\hline Switchgrass & 9.90 & 6.49 & 8.58 & 7.13 \\
\hline Rye & 3.88 & 3.29 & 3.42 & 2.42 \\
\hline $\begin{array}{l}\text { Sorghum x } \\
\text { sudangrass }\end{array}$ & 4.86 & 4.26 & 11.19 & 12.77 \\
\hline Sweet sorghum & 2.20 & 1.70 & 12.77 & 21.03 \\
\hline
\end{tabular}

${ }^{\mathrm{a}}$ Yields averaged across fertilizer levels.

results, but did not specifically make a recommendation for further energy crop research. Certainly the sweet sorghum and sorghum $\mathrm{x}$ sudangrass hybrids in a variety of cropping systems produced higher yields than any other annual or perennial species and maintained good yields under a variety of climate conditions.

The economic report from Iowa State University showed that based on costs alone, the annual sorghums dominated the perennials grasses in both locations tested. ${ }^{(21)}$ However, the economic analysis (Table 6) showed that the highest yielding perennial, switchgrass, competed well from an economic perspective with the sorghums, particularly with the intercropped sorghums which come closer to meeting environmental criteria. These results are bolded and highlighted by italics in Table 6.

The Iowa State University economic report summary states:

"The results for intercropped sorghum are mixed and depend on whether sufficient acres are produced to allow optimum equipment use. With optimum equipment use, intercropped sorghums are cheaper than switchgrass in central Iowa, but not southern Iowa. Soil conservation considerations clearly favor the perennial grasses or the intercrops."

\subsubsection{North Dakota State University - North Dakota}

Meyer et al. ${ }^{(18)}$ reported in 1994 that the establishment year of 1988 experienced record drought at all test locations. All perennial crops had to be reseeded with cool season grasses reseeded in fall 1988 and warm season grasses reseeded the following spring and watered through summer to aid germination. Watering was necessary because 1989 also received below normal rainfall conditions. By September reasonable to good stands of grasses had been obtained but the legumes were not successful. Annuals successfully established even in 1988 but did not set grain in the driest site and produced low yields at most other sites. All sites but the most westerly one received above normal or normal rainfall in 1990 and 1991 and 1992 was a near normal rainfall year for 4 of the 6 sites. ${ }^{(22)}$ 
Table 6. Costs and break -even prices of the crop production systems evaluated in Iowa 1988-1992 (from
Anderson et al. ${ }^{(21)}$ with English units converted to metric).

\begin{tabular}{|c|c|c|c|c|c|c|}
\hline \multirow[t]{2}{*}{ Crop Systems } & \multicolumn{3}{|c|}{ Ames $\left(\$ 283 \text { ha }^{-1} \text { land cost }\right)^{1}$} & \multicolumn{3}{|c|}{$\begin{array}{l}\text { Chariton (\$197 ha }{ }^{-1} \text { land }^{1} \\
\text { cost) }\end{array}$} \\
\hline & \multirow{2}{*}{$\frac{\text { Yield }}{\text { hry }^{-1}}$} & $\mathbf{A S C}^{2}$ & $A C^{3}$ & \multirow{2}{*}{$\begin{array}{l}\text { Yield } \\
\text { hay }^{-1}\end{array}$} & \multirow{2}{*}{\multicolumn{2}{|c|}{\begin{tabular}{l|l}
$\mathrm{ASC}^{-}$ & $\mathrm{AC}^{-1}$ \\
$\left(\right.$ dollar/dry $\left.\mathrm{Mg}^{-1}\right)$
\end{tabular}}} \\
\hline Monocrops & & (dolla & $\left.\mathrm{yg}^{-1}\right)$ & & & \\
\hline Alfalfa & 9.86 & 41.05 & 69.81 & 7.77 & 52.78 & \\
\hline Reed Canarygrass & 7.46 & 51.68 & 89.67 & 10.60 & 36.94 & 55.54 \\
\hline Switchgrass & 10.08 & 25.87 & 53.99 & 10.51 & 24.27 & 43.03 \\
\hline Big bluestem & 8.60 & 33.13 & 66.08 & 7.95 & 35.33 & 60.12 \\
\hline Sweet sorghum & 15.86 & 27.53 & 45.41 & 16.31 & 27.24 & 39.33 \\
\hline Sorghum x sudangrass & 14.47 & 29.51 & 49.09 & 14.25 & 30.26 & 44.10 \\
\hline \multicolumn{7}{|l|}{ Double Crops } \\
\hline Sweet sorghum/rye & 15.72 & 36.52 & 54.54 & 13.89 & 41.99 & 56.18 \\
\hline Sorghum x sudangrass/Rye & 14.52 & 38.98 & 58.51 & 13.87 & 41.80 & 56.02 \\
\hline Sweet sorghum ${ }^{3}$ & 14.96 & 26.48 & 45.42 & 16.02 & 25.40 & 37.71 \\
\hline Sweet Sorghum/Rye $e^{4}$ & 18.21 & 29.77 & 45.33 & 19.67 & 28.75 & 38.78 \\
\hline \multicolumn{7}{|l|}{ Intercrop } \\
\hline Sweet sorghum/Alfalfa & 13.89 & 31.48 & 51.89 & 9.61 & 45.03 & 65.55 \\
\hline Sorghum x sudangrass/Alfalfa & 13.66 & 31.72 & 52.47 & 11.56 & 37.98 & 55.18 \\
\hline Sweet sorghum/Reed Canary grass & 9.74 & 50.89 & 79.97 & -- & -- & -- \\
\hline Sorghum x sudangrass/Reed canarygrass & 9.88 & 49.98 & 78.67 & -- & -- & -- \\
\hline
\end{tabular}

Note: the four crops with lowest costs are highlighted for emphasis.

${ }^{1}$ Estimated based on average Iowa equipment use.

${ }^{2} \mathrm{ASC}=$ average specified cost (total specified cost divided by yield) includes all costs excluding land costs. ASC does include fixed expenses such as interest payments on and depreciation of machinery and on capital investments.

${ }^{3} \mathrm{AC}=$ average cost (total costs divided by yield) included the land cost and is the equivalent of break-even price.

${ }^{4}$ Sweet sorghum and sweet sorghum rye double crop in rotation with corn and soybean.

Perennial biomass yields averaged over all years and all fertilization levels was highest at Leonard, a "marginal" sandy site with wind erosion limitations. Prosper, the second site in the eastern Red River Valley area, produced the next highest perennial crop yields. The highest yielding biomass perennial crop at both sites was switchgrass (at 9 to $11 \mathrm{Mg} \mathrm{ha}^{-1}$ ). Intermediate wheatgrass, crested wheatgrass, a CRP mixture (consisting of wheatgrasses), and reed canarygrass followed close behind at about 7-9 dry $\mathrm{Mg} \mathrm{ha}^{-1}$. The warm season grasses did not establish well at the other sites to report yields, thus the most robust grass performance across all sites was demonstrated by the wheat grasses and CRP mixtures - though yields decreased to between 3-5 dry $\mathrm{Mg} \mathrm{ha}^{-1}$ except where irrigated. All annual crop yields were highest at the irrigated site in the drift prairie region, with the very highest multiyear average yield obtained by forage sorghum $\left(16.9 \mathrm{Mg} \mathrm{ha}^{-1}\right)$. Sorghum $\mathrm{x}$ sudangrass had very similar yields to that of forage sorghum in most years. Both the forage sorghum and sorghum $\mathrm{x}$ sudangrass displayed yields higher than the perennials in all locations. An annual weed, Kochia, provided the most surprising results. While it did not succeed as a volunteering species, in annually seeded plots, the yield of Kochia had yields nearly as high as the sorghums on the better sites and performed much better than all other species at the poorest site. ${ }^{(18)}$

Economic analysis, done on a whole-farm basis, was reported separately in a 1993 paper by Johnson et al. ${ }^{(23)}$ Kochia was the first crop to be included on farm plans in all regions, due to its very low input cost. However, there are problems in the management of Kochia. For instance, it must be harvested prior to frost to prevent large biomass losses and seed drop must be prevented to avoid infesting subsequent crops. If Kochia was excluded, then forage sorghum and sorghum $\mathrm{x}$ sudangrass 
were the most profitable biomass crops. Switchgrass was more profitable than the common small grains grown in the Red River Valley area.

While the performance of switchgrass in the North Dakota screening trials was limited due to its poor establishment at most sites, where adequate stands were obtained, it did show potential. Thus, the final report recommended that further research should be done on switchgrass in the Northern Great Plains.

\subsubsection{Oak Ridge National Laboratory - Tennessee}

An "old field" successional vegetation study conducted at ORNL during the same time frame as the herbaceous species screening studies and was affected by the same droughty conditions as many of the other studies. It provides a comparison not only with the species screening results, but also with recent studies in Minnesota on natural vegetation sites.

The sites studied by Johnston et al. ${ }^{(24)}$ were located on recently abandoned cropland and long abandoned pasture. Species diversity was high in both areas with the abandoned pasture having a higher percentage of grasses and lespedeza than the abandoned cropland which had significantly more composites that are typical weeds in cropland. Levels of productivity $\left(\sim 3.0\right.$ to $\left.8.0 \mathrm{Mg} \mathrm{ha}^{-1}\right)$ indicated that successional vegetation harvested during the unusually dry conditions of 1986-1988 was generally as productive as perennial, monocultural energy crops established in the southeastern U.S. during the same years. The successional vegetation was shown to be responsive to liming and fertilizers, although to a lesser extent than crops such as sweet sorghum and switchgrass. The fertilizer response was not sufficiently strong, however, to compensate for the added cost of the fertilizer applications. A preliminary economic assessment suggested that the most cost-effective treatment was no fertilization for an overall cost of about \$10/Mg (\$1990). After 3 years of biomass removal, there were no signs of depletion of the pools for the major or minor plant nutrients in the treatments that received no lime or fertilizer at either site. However, it was assumed that over the long term some additional lime treatment and nutrient replacement would be required. Nitrogen removal rates at harvest ranged from $\sim 40$ to $60 \mathrm{~kg} \mathrm{ha}^{-1}$ depending on harvest timing and yield levels. 


\subsection{HERBACEOUS CROP PROGRAM CONSIDERATIONS}

\subsection{HECP GOALS, ANALYSIS AND DATA SYNTHESIS}

By late 1987 the goals and objectives of the HECP had been refined to clearly state a sensitivity to environmental concerns and to working with industry. Cushman et al. clarified in the 1987 annual progress report ${ }^{(25)}$ that the overall goal of the HECP was "to work with industry and university researchers to provide a technology base that will allow industry to develop commercially viable systems for producing herbaceous biomass for fuels and energy feedstocks". The objectives of the HECP were expressed as follows:

1. Identify the biotic and physical resources available for the production of herbaceous energy crops.

2. Identify and improve the productivity of the species most appropriate for herbaceous energy crops

3. Define cost-effective management techniques for the production of herbaceous energy crops.

4. Establish the environmental acceptability and economic feasibility of herbaceous energy crops.

Included in the report ${ }^{(25)}$ was an analysis of the problem of erosion on croplands. HECP research managers had noted that the best yields for lignocellulosic crops were coming from annual grasses but there was substantial concern expressed about the amount of erosion associated with annual crops. An analysis was conducted by ORNL staff to examine the erosion potential of cropland and potential cropland that might be used for energy crops. Based on data from the 1982 National Resources Inventory, ${ }^{(26)}$ it was noted that about $50 \%$ of the total cropland base had a low erodibility factor of < 10 (based on the Universal Soil Loss Equation (USLE)). Almost any crop can be planted on this land and water caused erosion will remain less than the 5 tons/acre which was deemed an acceptable level by USDA's Soil Conservation Service (SCS), but much of that land is susceptible to wind erosion. It was further found that while only $12 \%$ of the cropland base had an erodibility factor of $50+$, it accounted for over $42.5 \%$ of water caused erosion on U.S. cropland with $70 \%$ of the losses associated with row crops. The USDA/SCS study ${ }^{(26)}$ stated that in the United States (in 1982), annual row crops had an averaged annual soil loss rate of $66 \mathrm{Mg} \mathrm{ha}^{-1}$, while hay crops (perennial and annual) average only 5.5 $\mathrm{Mg} \mathrm{ha}^{-1}$ ). This analysis indicated an important niche for perennial energy crops and was probably very influential in the final selection of a perennial grass as the single "model" species. Quoted from Cushman et al. ${ }^{(25)}$ is the following statement:

"Annual crops, especially energy crops that will leave little residue on the soil, are not appropriate for significant acreages of cropland. Perennial energy crops, especially grasses, are suitable for almost all cropland and potential cropland. They provide an opportunity to produce a crop on erosive land, yet achieve acceptable levels of soil protection."

The environmental concerns associated with growing annual crops on the types of marginal land included in the herbaceous screening trial studies were verified by analysis conducted by several of the collaborators. Examples of calculated erosion loss results comparing sorghum with perennial crop production systems are shown below (Tables 7 and 8). In Virginia, all species including sorghums were planted using no-till establishment on slopes of 4.5 to $10 \%$. The Virginia no-till management resulted in much lower levels of estimated erosion than was found for monoculture sorghums planted with conventional tillage on sloping sites in Chariton, Iowa. Of great interest, however, was the low amount of soil loss estimated when sorghum was intercropped with alfalfa or reed canary grass at the Chariton site (Table 8). ORNL had the responsibility of reviewing all of the herbaceous screening 
Table 7. Computed soil loss (mean of three sites) of eight no-till-planted species at four locations (three soils) in the Piedmont. Table reproduced from Virginia Tech final report. ${ }^{(11)}$

\begin{tabular}{|c|c|c|c|c|c|}
\hline Species/Conditions & $\begin{array}{l}\text { Amelia South } \\
\text { (Cecil) }\end{array}$ & $\begin{array}{l}\text { Amelia North } \\
\text { (Cecil) }\end{array}$ & $\begin{array}{l}\text { Orange } \\
\text { (Davidson) }\end{array}$ & $\begin{array}{l}\text { Lunenburg } \\
\text { (Appling) }\end{array}$ & $\begin{array}{l}\text { Average of } \\
\text { locations }\end{array}$ \\
\hline Sericea lespedeza & 4.19 & 2.33 & 4.55 & 1.70 & 3.19 \\
\hline Weeping lovegrass & 4.88 & 2.71 & 5.63 & 1.97 & 3.8 \\
\hline Flatpea & 5.07 & 2.81 & 5.33 & 2.06 & 3.82 \\
\hline Tall fescue & 5.27 & 2.93 & 5.16 & 2.15 & 3.88 \\
\hline Crownvetch & 5.12 & 2.84 & 5.99 & 2.07 & 4.00 \\
\hline Switchgrass & 5.87 & 3.26 & 6.71 & 2.39 & 4.56 \\
\hline Birdsfoot trefoil & 7.61 & 4.22 & 7.91 & 3.09 & 5.70 \\
\hline $\begin{array}{l}\text { Sorghum- } \\
\text { sudangrass }\end{array}$ & 13.98 & 7.75 & 14.36 & 5.67 & 10.44 \\
\hline Undisturbed land & 3.99 & 2.21 & 4.02 & 1.62 & 2.96 \\
\hline Soil loss tolerance ${ }^{\mathrm{a}}$ & 7 & 7 & 11 & 9 & 8.5 \\
\hline Soil formation rate ${ }^{b}$ & 1 & 1 & 1 & 1 & 1 \\
\hline
\end{tabular}

${ }^{\text {a }}$ Soil loss tolerance levels were derived for soils in the U.S. by soil scientists, agronomists, geologists, soil conservationists, and federal and state researchers in 1961 and 1962 (see report for references).

${ }^{\mathrm{b}}$ Soil formation rate for environmental sustainability (see report for references).

Table 8. Estimated soil loss under several crop systems in Iowa. Table reproduced from Iowa State University final report. ${ }^{(17)}$

Cropping system and crop

\begin{tabular}{|c|c|c|c|c|c|c|c|c|c|c|c|c|c|c|}
\hline \multirow[b]{2}{*}{ Year } & \multicolumn{6}{|c|}{ Monocrop } & \multicolumn{2}{|c|}{ Double crop } & \multicolumn{4}{|c|}{ Rotation } & \multicolumn{2}{|c|}{ Intercrop } \\
\hline & ALF & RCG & SWG & BBS & SS & SSH & SS/R & SSH/R & Corn & SB & SS/R & SS & ALF & RCG \\
\hline & \multicolumn{14}{|c|}{ Ames } \\
\hline 1988 & 3.79 & 3.79 & 3.92 & 3.92 & 4.89 & 4.89 & 3.06 & 3.06 & 4.41 & 3.92 & 3.06 & 4.89 & 3.79 & 3.79 \\
\hline 1989 & 0.25 & 0.04 & 0.04 & 0.04 & 4.89 & 4.89 & 3.06 & 3.06 & 4.41 & 4.88 & 3.06 & 4.89 & 0.25 & 0.04 \\
\hline 1990 & 0.25 & 0.04 & 0.04 & 0.04 & 4.89 & 4.89 & 3.06 & 3.06 & 4.41 & 4.88 & 3.06 & 4.89 & 0.25 & 0.04 \\
\hline 1991 & 0.25 & 0.04 & 0.04 & 0.04 & 4.89 & 4.89 & 3.06 & 3.06 & 4.41 & 4.88 & 3.06 & 4.89 & 0.25 & 0.04 \\
\hline 1992 & 0.25 & 0.04 & 0.04 & 0.04 & 4.89 & 4.89 & 3.06 & 3.06 & 4.41 & 4.88 & 3.06 & 4.89 & 0.25 & 0.04 \\
\hline \multicolumn{15}{|c|}{ Chariton } \\
\hline 1988 & 1.90 & 1.94 & 1.85 & 1.99 & 13.89 & 13.13 & 22.27 & 22.27 & 13.89 & 14.53 & 22.02 & 11.46 & 2.02 & 1.96 \\
\hline 1989 & 0.58 & 0.39 & 0.40 & 0.47 & 25.65 & 24.21 & 22.27 & 22.27 & 25.38 & 26.71 & 23.27 & 37.25 & 1.68 & 0.41 \\
\hline 1990 & 0.58 & 0.31 & 0.33 & 0.36 & 35.62 & 33.62 & 22.27 & 22.27 & 33.52 & 35.26 & 22.27 & 35.62 & 1.68 & 0.41 \\
\hline 1991 & 0.58 & 0.31 & 0.33 & 0.36 & 35.62 & 33.62 & 22.27 & 22.27 & 32.05 & 37.25 & 22.04 & 35.26 & 2.02 & 0.41 \\
\hline 1992 & 0.58 & 0.31 & 0.33 & 0.36 & 35.62 & 33.62 & 22.27 & 22.27 & 31.73 & 35.62 & 23.27 & 37.25 & 2.02 & 0.41 \\
\hline
\end{tabular}

Note $: \mathrm{ALF}=$ alfalfa, $\mathrm{RCG}=$ reed canarygrass, $\mathrm{SWG}=$ switchgrass, $\mathrm{BBS}=$ big bluestem, $\mathrm{SS}=$ sweet sorghum, $\mathrm{SSH}=$ sorghum $x$ sudangrass, $\mathrm{SS} / \mathrm{R}=$ sweet sorghum doublecropped with winter rye, $\mathrm{SSH} / \mathrm{R}=$ sorghum $\mathrm{x}$ sudangrass doublecropped with winter rye, Corn = corn in a corn-soybean-sorghum three year rotation, and Rotation = average factor for plots in the corn-soybean-sorghum rotation. 
studies and determining the patterns observed both within and between projects. Table 9 shows the crops recommended for further study and/or development by each project.

\begin{tabular}{ll}
\hline \multicolumn{1}{c}{ Table 9. Species recommended for further development or study by the seven herbaceous screening } \\
projects
\end{tabular}

While switchgrass was recommended by six of the seven projects, and performed reasonably well in the seventh project, it certainly was not always at the top of the recommendation list. Most of the projects that also recommended the sorghums tended to see them as being the more likely choice by farmers in their region. Turhollow et al. ${ }^{(27)}$ reported in the HECP Annual Progress Report for 1988 that the major observation across all screening projects was the superiority of both the sorghums and switchgrass under drought conditions. Switchgrass produced higher yields than sorghums in Virginia but both survived with no-till management in the poor Virginia soils. In Indiana, where late growing season rains did come in, sorghum produced as much as $32 \mathrm{Mg} \mathrm{ha}^{-1}$ at one site but, from an economic perspective, switchgrass was judged to have higher potential returns. In northern Ohio, the sorghums produced higher yields than the perennial grasses but yield declines over time were a concern. Sorghums performed well, while warm season perennials performed poorly when established in 1988 during drought conditions in North Dakota and Iowa. From an economic perspective, both sorghums and switchgrass generally stood out as having higher potential than other crop choices. The conclusions of the report ${ }^{(27)}$ indicate the opinion that sorghum may have potential for meeting economic requirements in the Midwest, but not the southeast. The only other crop that was recommended by more than one project was reed canarygrass. Energy cane and other subtropical grasses produced some very high yields that suggested further work might be merited in the south.

The ORNL graphic (Fig. 2), drawn in 1991, showing both the woody and herbaceous crops considered to be high potential included switchgrass, reed canarygrass, sorghum, and tropical grasses as the herbaceous crops of choice. The fact that ORNL scientists/research managers in the early 1990s still considered sorghum to be a high potential energy crop for some areas is evidenced by quotes from a 1991 paper presented by Cushman and Turhollow: ${ }^{(5)}$ 
"We now feel that sorghums will have an important role as energy crops on good sites, perhaps in rotation with conventional food crops where year-to-year flexibility in planting will be an advantage. However, their use on many lower quality sites will be limited by low production and environmental concerns."

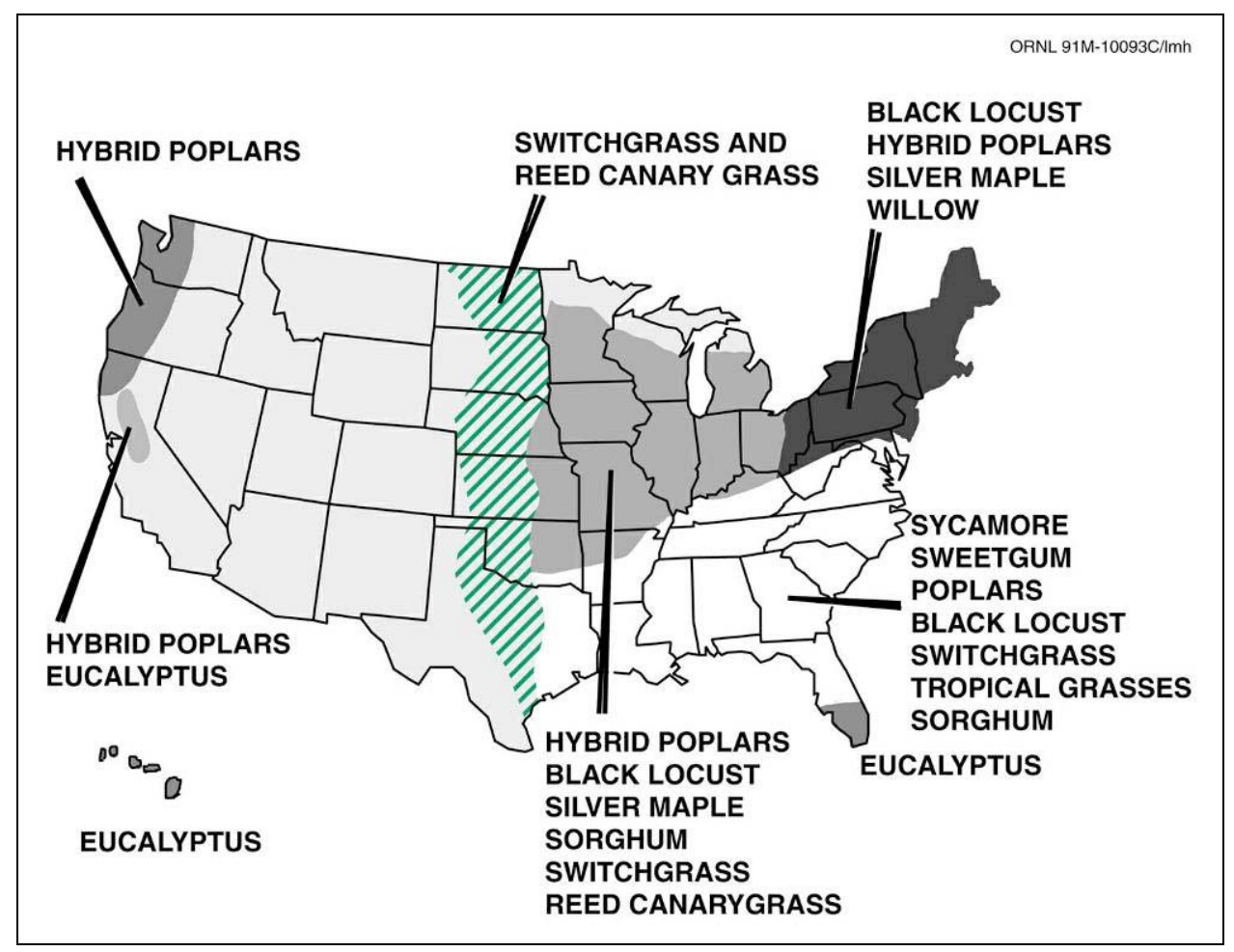

Figure 2. Woody and herbaceous species considered by the Department of Energy's Biofuels Feedstock Development Program as having high potential as energy crop feedstocks in 1991. The striped area had not completed herbaceous screening studies.

Given that ORNL was still identifying several species as having high potential for bioenergy in 1991, the question arises as to what really forced the choice to focus on a single model species. While switchgrass did stand out as an environmentally and economically sound choice for many parts of the country, it was not a clear winner in all locations. It is the opinion of this author that a combination of the original criteria established by the BFDP, the screening results, and funding limitations imposed by the Department of Energy resulted in selection of only a single herbaceous crop species for further development.

\subsection{BFDP FUNDING EFFECTS ON MODEL SPECIES SELECTION}

Funding variations in the program at ORNL in the early 1980s and 1990s (Fig. 3) had to affect research decisions in some manner. Substantial funding was received by ORNL to launch the new Herbaceous Energy Crops research effort in 1984. At the outset of the herbaceous program the expectation had been that at least 3 or 4 different types of herbaceous crops would be carried forward to further development after the screening phase. Funding remained relatively steady for 3 years but dropped substantially due to changes in government priorities before the planned end of the herbaceous crop screening phase. The funding drop coincided with the development of plans for 
further herbaceous and woody crop development. At this critical juncture, the decision was made jointly with DOE to restrict further crop development funding to very few "model" species. By focusing on only one herbaceous crop and one woody crop - it was believed there would be a greater chance for proving the value of genetics and biotechnology in increasing yields and improving economics.

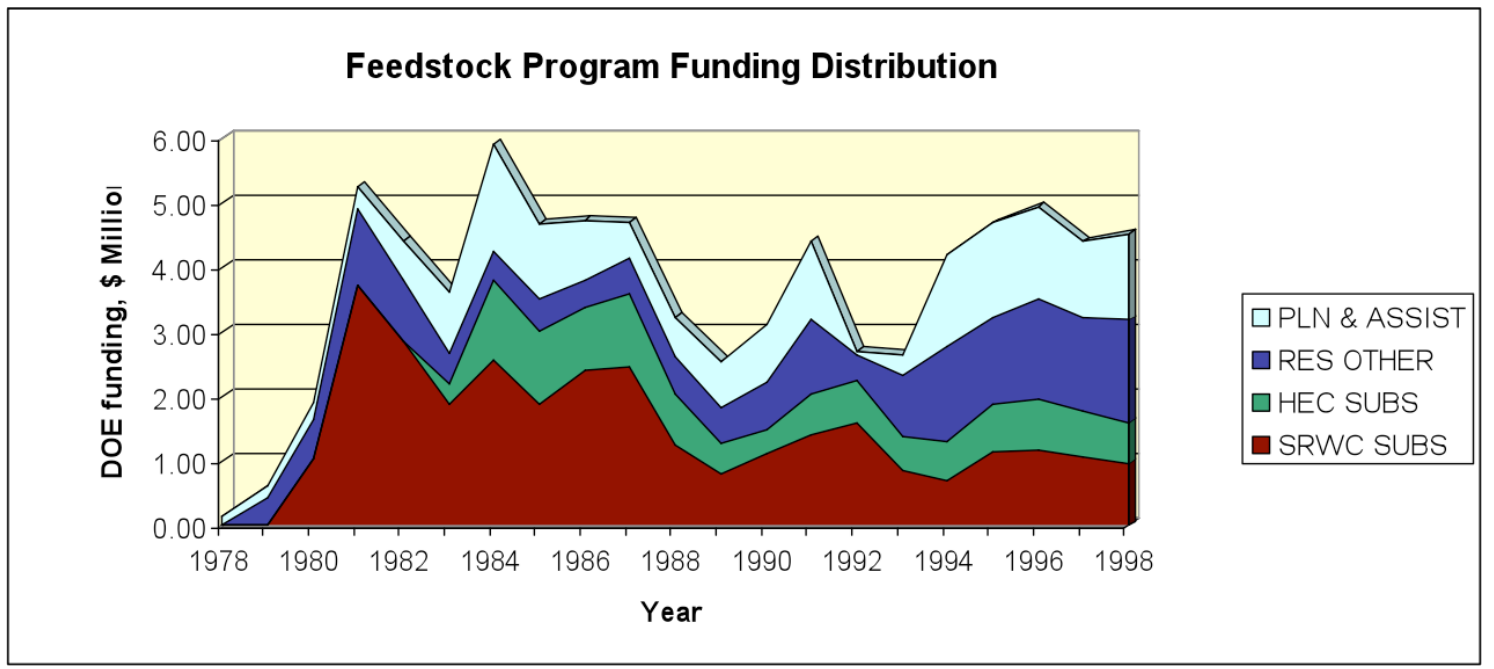

Figure 3. Funding history of the biofuels Feedstock Development Program between 1978 and 1998.

While the value of focusing was proven over the next several years, it is interesting to note that as feedstock funding at ORNL rebounded, crop development funding for both woody and herbaceous crop model species remained level while feedstock research expanded into new areas. In the early 1990s the woody and herbaceous crop development activities at ORNL were combined under the Biofuels Feedstock Development Program (BFDP). This joint program was proposed and accepted by DOE as a mission-oriented, national program of research and analysis whose goal was to develop and demonstrate environmentally acceptable crops and cropping systems for producing large quantities of low-cost, high quality biomass feedstocks. Thus, the goals of the BFDP went far beyond just developing crops to encompassing systems integration issues, optimizing economics, and considering feedstock quality, carbon sequestration issues, and biotechnology potential. Addressing these issues required close coordination with managers and researchers in DOE's Biofuels and Biopower Programs - responsible for developing technologies to convert biomass feedstocks to energy. Coordination needs also required more investment in outreach and communication and in analytical support to DOE. Thus, when funding increases occurred in the mid-1990s - it was allocated to new research topics, analysis, and outreach, rather than to expanding the number of species being developed. 


\section{HIGH POTENTIAL FEEDSTOCKS}

\subsection{HERBACEOUS CROPS CONSIDERED HIGH POTENTIAL IN 2006}

Research conducted specifically to improve switchgrass as a model biomass energy crop during the 1990s has been very successful in improving its potential as a dedicated biomass energy crop. McLaughlin and Kszos published in 2005 an excellent summary of the results gained by the focus on switchgrass. ${ }^{(3)}$ The research developments and the continued national level interest in biofuels development in the U.S. have been successful in attracting industry interest in further developing switchgrass. For instance, the private biotechnology firms, CERES and Mendal Biotechnology are both seriously working on the improvement of switchgrass for bioenergy.

New research conducted over the past 6 years at the University of Illinois has brought a lot of attention in the U.S. to a new crop that was identified as having high potential in Europe in the mid 1990s. ${ }^{(28)}$ Varieties of this crop, Miscanthus, have been grown for many years in the U.S. as a landscape plant, but it was never proposed for evaluation in any of the bioenergy crop screening studies. Because of the very high yields that have been obtained in Europe and which are now being replicated in Illinois with a single sterile hybrid cultivar, Miscanthus x giganteus (or giant Miscanthus), a legitimate question is being asked whether it should also be a "model" bioenergy crop and how it compares with switchgrass. Side by side studies in Illinois have certainly demonstrated a considerably higher yield potential for giant Miscanthus at the location tested. ${ }^{(29)}$ However, there is not yet published information discussing the economics and operational issues associated with establishing giant Miscanthus on a commercial scale - so a full comparison with switchgrass is difficult.

Sorghum continues to attract a lot of interest. Two presentations at the 2007 World BioCongress meetings held in Orlando, Florida, focused on the importance of sorghum as a cellulosic feedstock. The Kansas State University - StrathKirn Sorghum Project, currently focusing on bioconversion research, sees sorghum as the next most important crop (after corn) for ethanol. ${ }^{(30)}$ Geoffrey Thomas of SorBio Energy Systems made a presentation at the conference providing convincing information on why sorghum should be receiving more attention. ${ }^{(31)}$ Some of his arguments were the following:

1. Sorghums could be a starter crop that would fill the gaps in cellulosic feedstock production while perennial crops are becoming fully established.

2. Sorghums can be intercropped with winter cereals for multi-season cellulosic supplies.

3. Sorghums are adaptive to a wide range of soils conditions with several different varieties available to meet site specific requirements.

4. Low lignin hybrids are available in all key types of sorghum

5. Sorghum has a well known, fairly simple genome

6. The sorghum seed industry is well established and there is a large base of experienced producers

7. Sorghums have a large root system, are efficient water and nutrient users, and are simple and cost-effective to grow.

8. Forage sorghum dry land yields in Texas range from 7 to 22 dry $\mathrm{Mg} \mathrm{ha}^{-1}$, sweet sorghum yields are up to $\sim 17$ dry $\mathrm{Mg} \mathrm{ha}^{-1}$ and sorghum-sudangrass yields up to 14 dry $\mathrm{Mg} \mathrm{ha}^{-1}$ (with 3 cuttings).

9. Opportunities are available for further reduction in lignin levels and enhanced sugar yields through genetic improvement.

There are also downsides associated with sorghum harvest, handling, and storage that were not mentioned by Dr. Thomas but further consideration of sorghum appears to be merited. 
In 2006, a paper published in Science by Tillman et al. ${ }^{(32)}$ brought a lot of attention to "mixed grassland biomass" as an environmentally preferable, low-cost alternative resource for bioenergy in comparison to all monoculture crops. The paper focused on the energy input/output comparisons between growing corn grain for ethanol, soybeans for biodiesel, and grassland crops for biomass electric, biomass ethanol or biomass synfuels. The grassland crop based systems were shown to have significantly higher net energy balances (NEB) than either the corn grain to ethanol or soybeans to biodiesel. Yields of the grassland crops used in the NEB analysis (found in the published backup material) averaged 3.6 Mg ha $\mathrm{yr}^{-1}$ for the high diversity grassland plots on degraded soils and 6.0 $\mathrm{Mg} \mathrm{ha}^{-1} \mathrm{yr}^{-1}$ on fertile prairie soils, both in Minnesota. These yields were estimated from multiple replicates of very small samples that were harvested in early August of each year. If harvested in late September, yields would have likely been higher. An earlier publication ${ }^{(33)}$ had shown the positive relationship between increasing diversity and increasing yields with the mean yields of the highest diversity plots generally exceeding the highest yielding monoculture plots. However, the switchgrass monoculture plots had not established successfully and were not included in the 2001 comparison.

Some of the BFDP screening studies also noted the possible potential of mixed species plots (some were simply weeds, ${ }^{(14,18)}$ one was meadow grasses and legumes, ${ }^{(15)}$ and one was old field successional vegetation). ${ }^{(24)}$ Yields were generally in the range of 3 to $8 \mathrm{Mg} \mathrm{ha}^{-1}$. The results in North Dakota ${ }^{(18)}$ suggested that a low-input weed crop (Kochia) could be more profitable than conventional crops. Also, the old field successional vegetation study suggested the possibility of lowinput systems being profitable. ${ }^{(24)}$ The primary drawback to the low-input "meadow" biomass resource is that very large amounts of land would be required to produce the large supplies that will be needed for the large ethanol production facility sizes that are considered to be most cost-effective.

There are many other herbaceous crops that are still of interest to biomass energy crop developers. A DOE sponsored workshop held in $2006^{(34)}$ provided a group of crop experts from the southeast an opportunity to discuss the advantages and issues associated with potential biomass energy crop candidates. Crops that made the list included several annuals and perennials. Annuals included sorghum-sudangrass, sweet sorghum, johnsongrass, pearl millet, and industrial hemp. Perennials included giant reed, energy cane, switchgrass, giant Miscanthus, bermudagrass, napiergrass, bahiagrass, tall fescue, and sericea lespedeza. It would be of interest to evaluate all of the proposed bioenergy crops against a set of common criteria. Suggested criteria are described below.

\subsection{BIOFUELS FEEDSTOCK SELECTION CRITERIA}

Some important criteria for bioenergy feedstocks were recognized and established early in the screening process. Other criteria or valuable characteristics of bioenergy feedstocks were identified later as researchers and project developers began to seriously consider the factors necessary for putting together cost-effective feedstock supply systems. In order to maintain a historical perspective on which criteria lead to the selection of switchgrass as high potential "model" species, the criteria have been grouped by the decade in which there importance was more clearly recognized.

\subsubsection{0s Selection criteria}

In the early 80s, U.S. agricultural exports were at record levels and in 1984 the world became aware of famine in sub-Saharan Africa. Thus at the initiation of the trials in 1984 there was much more concern about possible conflicts between the production of food and fuel than existed at the end of the trials. ${ }^{(5)}$ Accordingly, the "capability of energy crops to perform on marginal cropland" was the broad objective at the time the herbaceous crop solicitation was issued. Crops which can meet that broad 
objective, however, have several characteristics that can be used as selection criteria. There is not a specific criteria related to conversion technology in this list. In the early 1980 s, the conversion technologies were presumed to have equal chance of being either biochemical or thermochemical so no criteria were established that would favor one type system over another. The only conversion related exclusions in the herbaceous crop screening solicitation ${ }^{(7)}$ were those that eliminated crops whose primary value lie in the production of specific chemical components, resins, latexes, oils, and hydrocarbons, or root, grain, or seed crops. Thus, corn grown primarily for production of grain to ethanol and beets grown for their sugar were not considered for further research by the Herbaceous Energy Crops Program.

\subsubsection{Profitability on marginal land}

The 1984 RFP $^{(7)}$ clarified that the objective of the research being initiated was to result in crop systems that were driven by "cost-effective production, not maximizing productivity per acre", recognizing that the crops producing the highest yields might not be the most profitable.

\subsubsection{Adaptability}

The trait of adaptability is not only associated with a capability to perform on marginal land, but is a necessary criteria for meeting the Herbaceous Energy Crop Program goal of identifying crops that would have the greatest possible impact on total biomass energy use. This was understood at the time to mean the selection of crops that were highly adaptable to production in many U.S. regions. Traits that contribute to adaptability include efficient nutrient use, efficient water use, tolerance of wet and dry soils, and freeze tolerance.

\subsubsection{Minimal soil loss}

Cropping systems that would minimize erosion were high on the list of desirable traits for an energy crop production system. The 1982 National Resources Inventory conducted by the USDA's Soil Conservation Service had determined that in the southeast and Midwest/Lake states, erosion was the most important restriction on cropland use and wetness was the second most important. ${ }^{(26)}$

\subsubsection{High yield potential and yield reliability}

While profitability, rather than high yields, was the ultimate goal, the identification of crops (and specific varieties within crops) with the best genetic potential for high yields and yield reliability was (and still is) important. High yield results from small field trials have to be evaluated in the context of nutrient and water inputs and variability of the crop yield under several years of variable climate conditions. Crops with the lowest input requirements and most stable yields are preferred.

\subsubsection{0s selection criteria}

By 1988, crop surpluses and the high costs of federal agricultural programs were emerging as national issues so "food versus fuel" concerns were greatly diminished. Also, late in the 1980s a serious attempt was made to begin linking energy crop production selection criteria to specific conversion technologies. ${ }^{(35)}$ 


\subsubsection{Profitability on productive land}

As research transitioned from screening trials to crop development trials, more research was performed on relatively better cropland and economic analysis using the resulting yields suggested that some crops had more potential than others to compete with conventional crops on cropland currently in production.

\subsubsection{Feedstock composition}

The importance of feedstock composition in affecting the success and cost of conversion technologies took on greater significance in the late 1980s and early 1990s. ${ }^{(5)}$ A literature review and survey published in $1988^{(36)}$ concluded that all conversion processes are affected by feedstock characteristics. The effects of composition on biochemical and thermochemical conversion were, for the most part, predictable - such as the problems caused by high ash contents, the value of high cellulose content for ethanol production, and the value of lignin for processes where higher btu levels are important. In about 1990, high nitrogen content was found by the Solar Energy Research Institution (now the National Renewable Energy Laboratory) to create problems for the simultaneous scarification and fermentation (SSF) approach to making ethanol. High nitrogen contributes to undesirable nitrogen compounds in the gases produced by thermochemical processes. ORNL funded composition studies showed that legumes had protein concentrations 2 to 4 times that of grass crops. Thus, the cost reductions that might be gained by the reduced fertilizer requirements of leguminous crops had to be weighed against the possible increased costs involved in producing clean fuels. ${ }^{(5)}$ This information led to basically dropping legumes from serious consideration by the ORNL/BFDP team.

\subsubsection{Reliable stand establishment}

The screening studies had shown the difficulty of establishing switchgrass during times of rainfall deficit. Several of the switchgrass crop development projects, focused on identifying causes for the problems and succeeded in developing more reliable methods. Reliability in stand establishment is a function both of crop characteristics and experience of the crop producer.

\subsubsection{Reliable low-cost propagation}

The ability to easily replicate the desired genetic traits using low-cost propagation techniques is important to the ability to reliably produce crops with the desired yield and composition traits. It is also important for facilitating rapid scale-up of the energy crop.

\subsubsection{Soil carbon sequestration}

The potential for herbaceous crops to affect soil carbon sequestration (either positively or negatively) also began to be a large issue in the early 1990s. More attention was given to looking at root systems and to collecting soil carbon data

\subsubsection{0s selection criteria}

By the early 2000s, the Biofuels Feedstock Program had already begun scaling up cultural methods developed in small research trials to larger scale/pre-commercial trials. Thus, the research community became more aware of crop scale-up and environmental issues, and the opportunity was created for testing a variety of harvesting, handling, storage, and transportation systems as well as collection of data on environmental effects. 


\subsubsection{Rapid scale-up potential}

As the idea of using perennial crop based bioenergy has moved from a concept to a recognized component of national energy plans, concerns have increased regarding the time it will take to produce sufficient seeds, rhizomes, cuttings, or seedlings to actually get a single large project established, much less, millions of acres of these new crops.

\subsubsection{Chemical inputs minimal}

With greater interest in bioenergy crops more questions are being asked about the possible impacts of the crops on the environment. Crops that can perform well with minimal chemical inputs clearly will have more support from environmental groups.

\subsubsection{Low pest and disease risk}

Crop that have few pest and disease problems will have greater potential for yield stability, higher yield potential, and consequently lower costs of production. This is often one of the attractive features of exotic species assuming that they do not have invasive characteristics.

\subsubsection{Invasive potential is low}

Increasing attention is being paid to the invasive characteristics of potential energy crops with several states excluding crops from consideration that have a high potential for becoming an invasive weed. Sometimes, exotic and invasive species are lumped together as though they are the same. In many cases, this is true, but not in all cases. Any potential exotic species should be evaluated to determine whether it has invasive characteristics before being widely planted in the U.S. and should be rejected if that potential exists. However, serious consideration should also be given to the potential yield advantages of exotics that are sterile, for example giant Miscanthus.

\subsubsection{Sterility}

Sterility is desirable, possibly even a requirement, for exotic species. Some investigators have also expressed a concern about the genetic contamination of wild populations of switchgrass from widespread planting of improved varieties. ${ }^{(37,38)}$

\subsubsection{Operational requirements}

There are a number of criteria associated with harvest, handling, and storage that can potentially be used in evaluating different species. Some identified in the table below include multiple harvest options, broad harvest window, and minimal storage needed. These are not as "fixed" as are basic plant characteristics but some crop types facilitate more options than other types and consequently the possibility of greater supply reliability at lower cost. ${ }^{(39)}$

\subsubsection{Net energy at feedstock harvest and at point of delivery}

A major point of controversy in recent years has been the amount of energy available in the final product versus the energy required to grow, harvest, transport, and convert the crop to its end use. Net energy available both in the harvested feedstock and in the delivered feedstock could be used to evaluate the relative desirability of different feedstock supply systems.

\subsubsection{Alternate uses}


Any energy crop will be more attractive to farmers if it has the potential of feeding into several possible markets. This will reduce the risk to the farmer in case a specific energy facility fails. 


\section{CHARACTERISTICS OF THE SWITCHGRASS "MODEL"}

The success that has been achieved in bringing attention to the potential of switchgrass as a feedstock for cellulosic ethanol has lead some to equate the term "model species" to mean "best species". When other crops have been found to produce higher yields in a given location, the first response is often to question the "model species" status given to switchgrass and to begin marketing the new crop as a "better" alternative. A more useful response would be to consider switchgrass as a "prototype" species that has been deemed capable of meeting many (though not necessarily all) of the criteria desired of a bioenergy crop.

Switchgrass is a good "prototype" for grass crop genetic improvement research due to its large genetic variability and the fact that recent research has elucidated much about the reproductive characteristics of the species. ${ }^{(40,41,42)}$ Switchgrass is a good prototype for harvest, handling, storage, and transport research because it can be grown under a wide rage of climate conditions and is amenable to being handled and stored both as a wet or dry feedstock. ${ }^{(39)}$ By focusing the energies of many different researchers on a selected prototype energy species, and facilitating the rapid exchange of information, it is possible to more quickly and fully develop an understanding of the issues involved in developing cost-effective, fully integrated crop supply systems for multiple regions of the U.S.

Table 10 attempts to (1) describe the current characteristics deemed desirable for bioenergy systems (and why they are desirable), (2) describe how well the switchgrass species and the assumed cropping systems meet those desired characteristics, and (3) provide references for further information.

\begin{tabular}{|c|c|c|c|}
\hline Criteria & $\begin{array}{l}\text { Relevance } \\
\text { categories }\end{array}$ & Rank & Notes and References \\
\hline $\begin{array}{l}\text { Cost- effective } \\
\text { production }\end{array}$ & Producer profitability & $\mathrm{H}$ & $\begin{array}{l}\text { Screening trials found switchgrass to be more } \\
\text { profitable than alternative conventional crops and } \\
\text { most grasses on marginal cropland in several parts of } \\
\text { the U.S. }(13,21,23) \text { Later analysis has demonstrated } \\
\text { that profitability depends greatly not only on } \\
\text { switchgrass technology (inputs, yields, storage, } \\
\text { transport) but also on farm, environmental and } \\
\text { energy policies and energy costs, all of which can } \\
\text { affect land prices and fertilizer and transport costs. }\end{array}$ \\
\hline Broad adaptability & $\begin{array}{l}\text { Producer } \\
\text { profitability, Supply } \\
\text { reliability }\end{array}$ & $\mathrm{H}$ & $\begin{array}{l}\text { The wide adaptability range of switchgrass was } \\
\text { demonstrated by the screening trials described in this } \\
\text { paper and by summary papers. }{ }^{(3,4)} \mathrm{pH} \text { ranges from } \\
4.9 \text { to } 7.6 \text { are tolerated. }{ }^{(41)}\end{array}$ \\
\hline $\begin{array}{l}\text { Tolerant of wet } \\
\text { and dry soils }\end{array}$ & $\begin{array}{l}\text { Producer } \\
\text { profitability, Supply } \\
\text { reliability } \\
\text { (subcomponent of } \\
\text { broad adaptability) }\end{array}$ & $\mathrm{M}$ & $\begin{array}{l}\text { Lowland varieties are naturally found in floodplains } \\
\text { and upland varieties are found in more well drained } \\
\text { areas. }^{(43)} \text { Screening studies found survival and } \\
\text { growth in both wet and dry areas. }\end{array}$ \\
\hline Freeze tolerant & $\begin{array}{l}\text { Producer } \\
\text { profitability, Supply } \\
\text { reliability } \\
\text { (subcomponent of } \\
\text { broad adaptability) }\end{array}$ & $\mathrm{H}$ & $\begin{array}{l}\text { Switchgrass has a range well into Canada and into } \\
\text { Mexico, thus some varieties are more freeze tolerant } \\
\text { than others. }{ }^{(43)}\end{array}$ \\
\hline
\end{tabular}




\begin{tabular}{|c|c|c|c|}
\hline $\begin{array}{l}\text { Efficient nutrient } \\
\text { use }\end{array}$ & $\begin{array}{l}\text { Producer } \\
\text { profitability, } \\
\text { Environmental } \\
\text { benefit (needs little } \\
\text { fertilizer) }\end{array}$ & M & $\begin{array}{l}\text { Fertilizer inputs in the range of } 40 \text { to } 120 \mathrm{~kg} \mathrm{~N} \mathrm{ha}^{-1} \\
\text { per year appear to be the most cost-effective levels } \\
\text { depending on region of the country and rainfall } \\
\text { levels. }{ }^{(3,43,44,45,46,47,48)} \text { Nutrient loss is greater with } \\
2 \text { or more cuts per year; best nutrient use efficiency } \\
\text { is } 1 \text { cut per year after senescence. }{ }^{(49,50)}\end{array}$ \\
\hline $\begin{array}{l}\text { Efficient water } \\
\text { use }\end{array}$ & $\begin{array}{l}\text { Producer } \\
\text { profitability, } \\
\text { Environmental } \\
\text { benefit (needs little } \\
\text { or no irrigation) }\end{array}$ & $\mathrm{H}$ & $\begin{array}{l}\text { The case for low water requirement derives primarily } \\
\text { from the observation that switchgrass remains green } \\
\text { when other forages turn brown from drought stress. } \\
\text { Roots are deeper than many grasses. Recent studies } \\
\text { on transpiration show differences among varieties. }{ }^{(11,} \\
51,48) \text { Precipitation levels may be critical to } \\
\text { successful establishment }{ }^{(3)} \text { but yields are not strongly } \\
\text { affected by precipitation after fully established. }{ }^{(3)}\end{array}$ \\
\hline $\begin{array}{l}\text { High yield } \\
\text { potential }\end{array}$ & $\begin{array}{l}\text { Producer } \\
\text { profitability, } \\
\text { Environmental } \\
\text { benefit (efficient } \\
\text { land use) }\end{array}$ & H-M & $\begin{array}{l}\text { High yields in the } 20 \text { to } 30 \text { dry } \mathrm{Mg} \mathrm{ha}^{-1} \text { range have } \\
\text { been demonstrated in a few locations, average yields } \\
\text { following switchgrass selection and development } \\
\text { tend to be in the range of } 10-20 \text { dry } \mathrm{Mg} \mathrm{ha}^{-1}{ }^{(3)} \\
\text { Breeding studies have indicated a potential to } \\
\text { improve yields at a rate of } 5 \% \text { or greater per } \\
\text { breeding cycle. }{ }^{(40)}\end{array}$ \\
\hline Alternate uses & Producer profitability & $\mathrm{H}$ & $\begin{array}{l}\text { A farmer's co-op in Iowa is developing several } \\
\text { markets for switchgrass including forages, mulch for } \\
\text { landscaping, fiberboard and paper, plastics filler, } \\
\text { stove pellets, fireplace logs, and animal bedding. }{ }^{\left({ }^{60)}\right.}\end{array}$ \\
\hline Yield reliability & Supply reliability & $\mathrm{H}$ & $\begin{array}{l}\text { Yield reliability in many soil and climate conditions } \\
\text { is higher than most annuals and better than many } \\
\text { perennials based on screening trial results }{ }^{(12,13,14,15} \\
16,17,18)\end{array}$ \\
\hline $\begin{array}{l}\text { Pests and disease } \\
\text { problems are } \\
\text { minimal }\end{array}$ & $\begin{array}{l}\text { Supply reliability, } \\
\text { Producer } \\
\text { profitability, } \\
\text { Environmental } \\
\text { benefit (low } \\
\text { chemical use) }\end{array}$ & $\mathrm{H}$ & $\begin{array}{l}\text { Pest and disease incidence has been very low thus far } \\
\text { but some pests and diseases have been identified. } \\
\text { Research in Virginia has shown an advantage to } \\
\text { using a granular systemic insecticide in rows at time } \\
\text { of planting reducing need for any further insecticide } \\
\text { use. }{ }^{(53)}\end{array}$ \\
\hline $\begin{array}{l}\text { Easily/reliable } \\
\text { propagation }\end{array}$ & $\begin{array}{l}\text { Supply reliability, } \\
\text { Producer profitability }\end{array}$ & $\mathrm{M}$ & $\begin{array}{l}\text { Seed production is easy but controlled crossing is } \\
\text { required. High demand for improved varieties is } \\
\text { already increasing seed costs. Micro propagation of } \\
\text { genotypes is possible but costly. }{ }^{(56)}\end{array}$ \\
\hline $\begin{array}{l}\text { Quick/reliable } \\
\text { stand } \\
\text { establishment }\end{array}$ & $\begin{array}{l}\text { Supply reliability, } \\
\text { Producer profitability }\end{array}$ & $\begin{array}{l}\mathrm{M} \text { to } \\
\mathrm{L}\end{array}$ & $\begin{array}{l}\text { Many of the screening trials reported very slow } \\
\text { establishment rates ( } 3 \sim 4 \text { years) while some later } \\
\text { studies achieved full yield by the } 2^{\text {nd }} \text { year. Seeding } \\
\text { failures may occur if seed dormancy is not broken }{ }^{(47,} \text {, } \\
48,53,54) \text { or if rainfall is not sufficiently frequent. }\end{array}$ \\
\hline $\begin{array}{l}\text { Soil carbon } \\
\text { sequestration rate } \\
\text { potential is high }\end{array}$ & $\begin{array}{l}\text { Environmental } \\
\text { benefit (soil } \\
\text { improvement, low } \\
\text { GHG emissions) }\end{array}$ & $\mathrm{H}$ & $\begin{array}{l}\text { The deep rooting system of switchgrass allows crop } \\
\text { to initially sequester carbon at a high rate ( } 1 \text { to } 1.6 \\
\mathrm{Mg} \mathrm{C}_{58,59)} \text { ha- }^{-} \text {) if production site is carbon depleted. }\end{array}$ \\
\hline $\begin{array}{l}\text { Soil loss is } \\
\text { minimal }\end{array}$ & $\begin{array}{l}\text { Environmental } \\
\text { benefit (sustainable } \\
\text { productivity) }\end{array}$ & $\mathrm{H}$ & $\begin{array}{l}\text { Most perennials result in lower soil loss than annual } \\
\text { crops even when planted into conventionally tilled } \\
\text { soils, but no till establishment results in the least soil } \\
\text { loss. }{ }^{(12,17)}\end{array}$ \\
\hline
\end{tabular}




\begin{tabular}{|c|c|c|c|}
\hline $\begin{array}{l}\text { Chemical inputs } \\
\text { minimal }\end{array}$ & $\begin{array}{l}\text { Environmental } \\
\text { benefit (low GHG } \\
\text { emissions), Producer } \\
\text { profitability }\end{array}$ & M & $\begin{array}{l}\text { Herbicides are generally required in first year for } \\
\text { successful establishment, but rarely thereafter; } \\
\text { mowing above the new seedlings is sometimes } \\
\text { sufficient; there has been little need for pesticides. }{ }^{(46,} \text {, }\end{array}$ \\
\hline $\begin{array}{l}\text { Chemical inputs } \\
\text { minimal }\end{array}$ & $\begin{array}{l}\text { Addresses an } \\
\text { important } \\
\text { environmental } \\
\text { criteria }\end{array}$ & $\mathrm{H}$ & $\begin{array}{l}\text { Herbicides are generally required in first year for } \\
\text { successful establishment, but rarely thereafter; } \\
\text { mowing above the new seedlings is sometimes } \\
\text { sufficient; there has been little need for } \\
\text { insecticides. }{ }^{(46,47,53)}\end{array}$ \\
\hline $\begin{array}{l}\text { Energy input to } \\
\text { energy crop } \\
\text { production is low }\end{array}$ & $\begin{array}{l}\text { Environmental } \\
\text { benefit (low GHG } \\
\text { emissions), Producer } \\
\text { profitability }\end{array}$ & $\mathrm{H}$ & $\begin{array}{l}\text { Energy input requirements are between } 3 \text { and } 4 \% \text { of } \\
\text { the HHV of the pre-harvest production at yields } \\
\text { ranging from } 10 \text { to } 30 \text { dry } \mathrm{Mg} \mathrm{ha}^{-1} \text { and optimized } \\
\text { fertilization levels. }\end{array}$ \\
\hline $\begin{array}{l}\text { Energy input of } \\
\text { delivered } \\
\text { feedstock is low }\end{array}$ & $\begin{array}{l}\text { Environmental } \\
\text { benefit (low GHG } \\
\text { emissions), Producer } \\
\text { profitability }\end{array}$ & $\mathrm{H}$ & $\begin{array}{l}\text { Total energy input requirements for crop production, } \\
\text { harvest and storage, and transport with both current } \\
\text { and mature technologies are estimated to be } 8.5 \% \text { or } \\
\text { below at current yields }\left(10 \mathrm{Mg} \mathrm{ha}^{-1}\right) \text {, reducing to } \\
6.5 \% \text { at } 30 \mathrm{Mg} \mathrm{ha}^{-1} \text { with mature technology. }{ }^{(39)}\end{array}$ \\
\hline $\begin{array}{l}\text { Invasive potential } \\
\text { is low }\end{array}$ & $\begin{array}{l}\text { Environmental } \\
\text { benefit (low risk) }\end{array}$ & $\mathrm{H}$ & $\begin{array}{l}\text { Switchgrass is a native species that is persistent once } \\
\text { established, but not overly aggressive in spreading to } \\
\text { new areas. }{ }^{(43)}\end{array}$ \\
\hline $\begin{array}{l}\text { Sterility is natural } \\
\text { or can be created }\end{array}$ & $\begin{array}{l}\text { Environmental } \\
\text { benefit (low risk) }\end{array}$ & M-L & $\begin{array}{l}\text { Switchgrass is an out crossing species, thus large } \\
\text { populations of naturally selected "improved" } \\
\text { varieties planted near remnant native populations, } \\
\text { might result in changing some traits in the native } \\
\text { populations; this area needs more research to } \\
\text { determine risk levels, distance of effects, and } \\
\text { potential for creating sterile varieties. }\end{array}$ \\
\hline $\begin{array}{l}\text { Rapid commercial } \\
\text { scale-up possible }\end{array}$ & $\begin{array}{l}\text { Supply logistics } \\
\text { (enabler of near-term } \\
\text { commercial success) }\end{array}$ & $\mathrm{M}$ & $\begin{array}{l}\text { Scaling up of stands of select varieties to propagate } \\
\text { enough seed for several large projects } \\
\text { simultaneously would be a problem, probably taking } \\
\text { 3-5 years at a minimum. However, farmers are } \\
\text { interested if markets emerge. }{ }^{(60)}\end{array}$ \\
\hline $\begin{array}{l}\text { Multiple harvest } \\
\text { options }\end{array}$ & $\begin{array}{l}\text { Supply logistics } \\
\text { (allows greater } \\
\text { adaptability of the } \\
\text { production system) }\end{array}$ & $\mathrm{H}$ & $\begin{array}{l}\text { The thin stemmed switchgrass at current yield levels } \\
\text { is amenable to conventional mowing and } \\
\text { conditioning, and can be field chopped and ensiled, } \\
\text { or swathed and baled in either round bales, small or } \\
\text { large square bales or "loafs" for dry storage or } \\
\text { further handling (e.g. pelletizing). Higher yield } \\
\text { levels will likely require modifications to equipment } \\
\text { and/or development of more innovative designs. }\end{array}$ \\
\hline $\begin{array}{l}\text { Harvest window is } \\
\text { broad }\end{array}$ & $\begin{array}{l}\text { Supply logistics } \\
\text { (increases probability } \\
\text { that majority of crop } \\
\text { can be harvested) }\end{array}$ & $\mathrm{M}$ & $\begin{array}{l}\text { While switchgrass can theoretically be harvested } 2 \text { or } \\
\text { more times during the growing season, in fall and } \\
\text { even in the following spring - the most sustainable } \\
\text { system for most regions is one harvest per year in } \\
\text { fall after senescence. Spring harvests risk a } 30 \text { to } \\
40 \% \text { yield reduction compared to fall harvest. }{ }^{(58,61)}\end{array}$ \\
\hline $\begin{array}{l}\text { Storage time is } \\
\text { minimal }\end{array}$ & $\begin{array}{l}\text { Supply logistics } \\
\text { (reduces cost, } \\
\text { minimizes loss, } \\
\text { reduces changes in } \\
\text { composition) }\end{array}$ & $\mathrm{L}$ & $\begin{array}{l}\text { The downside of one harvest per year is that the } \\
\text { biomass must be stored for longer periods. } \\
\text { Development of storage methods that minimize } \\
\text { losses are a major research effort. }{ }^{(39)}\end{array}$ \\
\hline Composition & Conversion & $\mathrm{M}$ & Optimal composition for ethanol made with the SSF \\
\hline
\end{tabular}




\begin{tabular}{|l|l|l|}
$\begin{array}{l}\text { (must be specified } \\
\text { based on planned } \\
\text { conversion } \\
\text { process) }\end{array}$ & $\begin{array}{l}\text { efficiency (final } \\
\text { product cost) }\end{array}$ & $\begin{array}{l}\text { process includes high cellulose, low ash, low } \\
\text { nitrogen and just enough lignin to reduce facility } \\
\text { power costs. Other biofuel processes may prefer } \\
\text { more nitrogen (proteins) or more lignin to produce a } \\
\text { greater variety of co-products. Switchgrass has } \\
\text { higher cellulose levels and lower ash levels } \\
\text { compared to many other herbaceous crops } \\
\text { screened } \\
\text { fast growing trees. }\end{array}$ \\
\hline
\end{tabular}




\section{CONCLUSION}

The screening trials funded by the U.S. Department of Energy in the late 1980s to early 1990s assessed a wide range of about 34 species with trials being conducted on a wide range of soil types in 31 different sites spread over seven states in crop producing regions of the U.S. Several species were identified as having merit for further development. Six of the seven institutions included switchgrass among the species recommended as having high potential in their region and/or deserving of further study. Most projects had some to serious problems with switchgrass establishment during drought years, but later crop development research identified methods to improve establishment success under most conditions. The two southeast projects, in Virginia and Alabama, had the most success with switchgrass and produced some of the most persuasive information showing the merits of switchgrass - especially the potential for high yields, its deep rooting characteristics, and its potential value in carbon sequestration. All of the Midwest projects (in Indiana, Iowa, and North Dakota) came to the conclusion that switchgrass merited further consideration primarily after conducting economic analysis, since visual results of crop yields most often led toward favoring sorghum systems. In some cases, additional characteristics such as more favorable conversion characteristics or lower erosion potential increased the interest in switchgrass. Economic and environmental assessments by Oak Ridge National Laboratory's Biofuels Feedstock Development Program staff together with the screening project results, and funding limitations lead to making the decision to further develop only switchgrass as a "model" or "prototype" species in 1991.

Selection of switchgrass as a model species in 1991 lead to a switchgrass specific solicitation and then to 10 years of switchgrass development at ten institutions under the management of Sandy McLaughlin and others at ORNL. ${ }^{(3)}$ More recently switchgrass has been the focus of investigations at several additional universities and private institutions. New varieties have been developed and released, management techniques have been improved, and much more is now known about how switchgrass can be harvested, handled, stored and converted to ethanol or used to produce power. Now, in 2007, it is very apparent that while switchgrass may not be a perfect energy crop (and there may not be a perfect crop), it has many valuable characteristics that will result in its continuing to be not only a "model or prototype" for crop development, but also one of the more sustainable feedstocks for the production of renewable alternative fuels in the U.S.

There are many herbaceous crops that are still of interest to biomass energy crop developers. A DOE sponsored workshop held in $2006^{(34)}$ provided a group of crop experts from the southeast an opportunity to discuss the advantages and issues associated with potential biomass energy crop candidates. Crops that made the list included several annuals and perennials. Annuals included sorghum-sudan grass, sweet sorghum, johnsongrass, pearl millet, and industrial hemp. Perennials included giant reed, energy cane, switchgrass, giant Miscanthus, bermudagrass, napiergrass, bahiagrass, tall fescue, and sericea lespedeza. Regional and local considerations may well favor use of an herbaceous energy crop other than switchgrass. It is important, however, that any crop used for bioenergy be capable of being produced in a way that is not only economically sustainable but that also meets high standards of environmental sustainability. 


\section{REFERENCES}

1. L.L. Wright, J.H. Cushman, A.R. Ehrenshaft, S.B. McLaughlin, S.A. Martin, W.A. McNabb, J.W. Ranney, G.A. Tuskan, A.F. Turhollow, Biofuels Feedstock Development Program Annual Progress Report for 1992. ORNL-6781. Oak Ridge National Laboratory, Oak Ridge, TN 37831,1993.

2. S.E. Sladden, D.I. Bransby, and G.E. Aiken, Biomass, Yields, Composition, and Production Costs for Eight Switchgrass Varieties in Alabama, Biomass and Bioenergy Vol 1(2): 119-122, 1991.

3. S.B. McLaughlin, and L.A. Kszos. Development of switchgrass (Panicum virgatum) as a bioenergy feedstock in the United States. Biomass and Bioenergy 28 (2005):515-535, 2005.

4. S.B. McLaughlin, New Switchgrass Biofuels Research Program for the Southeast, pp.111-115, In: Proceedings of the Annual Automotive Technology Development Contractors' Coordination Meeting. SAE International, Warrendale Pennsylvania, 1992.

5. J. H. Cushman and A.F. Turhollow, "Selecting Herbaceou Energy Crops for the Southeast and Midwest/Lake States" pp. 465-480 In: Energy from Biomass and Wastes XIV, D.L. Klass (ed), Institute of Gas Technology, Chicago, Illinois, 1991.

6. SERI. The Production of Herbaceous Feedstocks for Renewable Energy. SERI/SP-273-2302, DE85012136 Solar Energy Research Institute, Golden, Colorado 80401-3393, 1986.

7. Oak Ridge National Laboratory (ORNL). Request for Proposal No. 19-6233 Entitled "Selection of Herbaceous Species for Energy Crops". Released by Oak Ridge National Laboratory's Bioenergy Feedstock Development program approximately March 1984 with proposals due July 17, 1984.

8. OTA. Energy from biological processes. Congress of the United States Office of Technology Assessment. U.S. Government printing Office 0-65-498. Washington, D.C., 1980.

9. J.B. Berger, and J.H. Cushman, Herbaceous Energy Crops - Planning for a renewed Commitment, Environmental Sciences Division Publication No. 2385. Oak Ridge National Laboratory Biomass/ Feedstock Development Program, Oak Ridge, TN, 1984.

10. J.H. Cushman, A.F. Turhollow, and J.W. Johnston. Herbaceous Energy Crops Program: Annual Progress Report for FY 1985. ORNL - 6263. Oak Ridge National Laboratory, Oak Ridge, TN, 19896.

11. D.J. Parrish, D.D. Wolf, W.L. Daniels, D.H. Vaughan, and J.S. Cundiff. Perennial Species for Optimum Production of Herbaceous Biomass in the Piedmont, Final Report 1985-1989. ORNL/Sub/85-27413/5, submitted to the Biomass Feedstock Development Program, Oak Ridge National Laboratory, Oak Ridge, Tennessee, 1990.

12. D.J. Parrish, D.D. Wolf, and W.L. Daniels. Perennial Species for Optimum Production of Herbaceous Biomass in the Piedmont (Management Study, 1987 - 1991): Final Report. ORNL/Sub/85-27413/7, submitted to the Biomass Feedstock Development Program, Oak Ridge National Laboratory, Oak Ridge, Tennessee, 1993.

13. D.I. Bransby, S.E. Sladden, and D.D. Kee, Selection and Improvement of Herbaceous Energy Crops for the Southeastern USA, Final Report in a Field and Laboratory Research Program for the period March 15, 1985 to March 19, 1990, ORNL/Sub//85-27409/5, Oak Ridge National Laboratory Biomass/ Feedstock Development Program, Oak Ridge, TN, 1990.

14. N. Wright, Screening of Herbaceous Species for Energy Crop Production: Final Report 1985-1990, ORNL/Sub/85-27411/5, 1990.

15. R.A. Pfeifer, G.W. Fick, D.J. Lathwell, and C. Maybee. Screening and Selection of Herbaceous Species for Biomass Production in the Midwest/Lake States: Final Report 1985-1989. ORNL/Sub/85-27410/5, submitted to the Biomass Feedstock Development Program, Oak Ridge National Laboratory, Oak Ridge, Tennessee, 1990.

16. J.H. Cherney, K.D. Johnson, J.J. Volenec, E.J. Kladivko, and D.K. Greene. 1990. Evaluation of Potential Herbaceous Biomass Crops on Marginal Crop Land (1) Agronomic Potential. ORNL/Sub/85-27412/5\&P1, submitted to the Biomass Feedstock Development Program, Oak Ridge National Laboratory, Oak Ridge, Tennessee, 1990.

17. I.C. Anderson, D.R. Buxton, and J.A. Hallam,, Selection of Herbaceous Energy Crops for the Western Corn Belt. Final Report Part I: Agronomic Aspects. ORNL/Sub/88-SC264/P1, Oak Ridge National Laboratory Biomass/ Feedstock Development Program, Oak Ridge, Tennessee, 1994. Available at http://bioenergy.ornl.gov/main.aspx (use search function). 
18. D.W. Meyer, W.E. Norby, D.O. Drickson, and R.G. Johnson. Evaluation of Herbaceous Biomass Crops in the Northern Great Plains. ORNL/Sub/88-SB844/2. Oak Ridge National Laboratory. Oak Ridge, TN 37880, 1994. Available at http://bioenergy.ornl.gov/main.aspx (use search function).

19. G.W. Fick, R.A. Pfeifer, and D.J. Lathwell. Production Patterns of Perennial Herbaceous Biomass Crops in the Great Lakes Region. Energy Sources 16:333-348, 1994.

20. C.L. Dobbins, P. Preckel, A. Mdafri, J. Lowenberg-DeBoer, and D. Stucky. Evaluation of Potential Herbaceous Biomass Crops on Marginal Crop Lands: (2) Economic Potential Final Report 19851989. ORNL/Sub/85-27412/5\&P2. Oak Ridge National Laboratory, Oak Ridge, TN. 37880, 1990.

21. I.C. Anderson, D.R. Buxton, and J.A. Hallam, Selection of Herbaceous Energy Crops for the Western Corn Belt. Final Report Part II: Economic Potentials, ORNL/Sub/88-SC264/P2, Oak Ridge National Laboratory Biomass/ Feedstock Development Program, Oak Ridge, TN, 1994.

22. D.W. Meyer, D.E. Lippert, D.O. Erickson, and R.G. Johnson, Evaluation of Herbaceous Biomass Crops in the Northern Great Plains: 1990 Annual Report, ORNL/Sub/19X-SB844C/3. Oak Ridge National Laboratory, Oak Ridge TN37880, 1991.

23. R.G. Johnson, R.S. Sell, and D.W. Meyer. Economic Evaluation of Herbaceous Biomass Crops in the Northern Great Plains-Economic Analysis. Report on Subcontract No. 19x-SB844c. Oak Ridge National Laboratory, Oak Ridge, TN. 37880, 1991.

24. J.W. Johnston, Jr. Evaluation of the Potential for Using Old-Field Vegetation as an Energy Feedstock: Biomass Yield, Chemical Composition, Environmental Concerns, and Economics. ORNL/TM-11615 Oak Ridge National Laboratory, Oak Ridge, TN 37880, 1990. Available at http://bioenergy.ornl.gov/main.aspx (use search function).

25. J.H. Cushman, A.F. Turhollow, and J.W. Johnston. Herbaceous Energy Crops Program Annual Progress Report for FY 1987. ORNL-6514. Oak Ridge National Laboratory, Oak Ridge, TN, 1989.

26. U.S. Department of Agriculture Soil Conservation Service, Basic Statistics 1982 National Resources Inventory, Statistical Bulletin No. 756, Iowa State University Statistical laboratory. September 1987.

27. A.F. Turhollow, J.H. Cushman, and J.W. Johnston. Herbaceous Energy Crops Program: Annual Progress Report for FY 1988. ORNL-6639. Oak Ridge National Laboratory, Oak Ridge, TN, 1990.

28. E. Heaton, T. Voight, and S.P. Long. A quantitative review comparing the yields of two candidate $C 4$ perennial biomass crops in relation to nitrogen, temperature, and water. Biomass and Bioenergy 27 (2004): 21-30, 2004a.

29. E.A. Heaton, J. Clifton-Brown, T.B. Voight, M.B. Jones, and S.P. Long. Miscanthus for Renewable Energy Generation: European Union Experience and Projections for Illinois. Mitigation and Adaptation Strategies for Global Change 9: 433-451, 2004b.

30. J. McLaren, Sorghum BioConversion Research: Sorghum - The Next Most Important Crop for Ethanol, Presented at the 2007 World Congress on Industrial Biotechnology and Bioprocessing, Orlando, Florida, Mar 21-24, 2007.

31. G. Thomas, The Role of the Genus Sorghum as a Cellulosic Bio-feedstock, Presented at the 2007 World Congress on Industrial Biotechnology and Bioprocessing, Orlando, Florida, Mar 21-24, 2007.

32. D. Tillman, J. Hill, and C. Lehman. Carbon-Negative Biofuels from Low-Input High-Diversity Grassland Biomass. Science 8 December 2006:314:1598-1600. DOI: 10.1126/science.1133306.

33. David Tillman, Peter B. Reich, Johannes Knops, David Wedin, Troy Mielke, and Clarence Lehman. Diversity and Productivity in a Long-Term Grassland Experiment. Science 26 October 2001: Vol. 294. no. 5543, pp. 843 - 845, DOI: 10.1126/science. 1060391.

34. Department of Energy, Office of Biomass Program. $30 \times 30$ Workshop. 2006. Notes available at www.30x30workshop.biomass.govtools.us

35. Turhollow, A.F., J.W. Johnston, and J.H. Cushman. Linking Energy Crop Production to Conversion: The Case of Herbaceous Lignocellulosic Crops to Ethanol. RERIC International Energy Journal: Vol. 10, No. 2 (41-49), December 1988.

36. R.S. Butner, D.C. Elliot, L.J. Sealock, Jr., and J.W. Pyne, Effect of Biomass Feedstock Chemical and Physical Properties on Energy Conversion Processes, PNL6575 Vols. 1 and 2. Pacific Northwest Laboratory, Richland, WA 1988.

37. K.P. Vogel and G.J. Hans-Joachim, Genetic Modification of Herbaceous Plants for Feed and Fuel, Critical Reviews in Plant Sciences 20(1): 15-49, 2001.

38. A.A. Snow, Transgenic crops-Why Gene Flow Matters, Nature Biotechnology 20:542, June 
2002.

39. S. Sokhansanj, S. Mani, A.Turhollow, A. Kumar, D. Bransby, L. Lynd, M. Laser, Large Scale Production, Harvest and Transport of a Switchgrass (Panicum virgatum L.) Current Technology and Visioning a Mature Technology. Manuscript submitted for publication to Biomass and Bioenergy in June 2007.

40. C. M. Taliaferro, K.P. Vogel, J.H. Bouton, S.B. McLaughlin, and G.A. Tuskan, Reproductive Characteristics and Breeding Improvement Potential of Switchgrass. In: "Proceedings of the $4^{\text {th }}$ biomass Conference of the Americas - Biomass, A Growth Opportunity in Green Energy and ValueAdded Products" (R. Overend and E. Chornet, Eds.) pp. 147-153. Elsivier Sciences, Oxford, United Kingdom, 1999.

41. C.M. Taliaferro, Breeding and Selection of New Switchgrass Varieties for Increased Biomass Production. ORNL/SUB-02-19XSY162C/01. Oak Ridge National Laboratory, Oak Ridge, Tennessee. 2002. Available at: http://bioenergy.ornl.gov/main.aspx (search by author).

42. K.P. Vogel, Genetic Improvement of Switchgrass and Other Herbaceous Plants for Use as Biomass Fuel Feedstock: Final Report, ORNL/SUB/90-90OR21954/1, Oak Ridge National Laboratory, Oak Ridge, TN. Available at: http://bioenergy.ornl.gov/main.aspx (search by author).

43. L.E. Moser and K.P. Vogel, Switchgrass, Big Bluestem, and Indiangrass, pp. 409-420 In: Forages Volume 1: An Introduction to Grassland Agriculture (eds R.F. Barnes, D.A. Miller, C.J. Nelson), Iowa State University Press, Ames Iowa 50014, 1995.

44. K.P. Vogel, J.J. Brejda, D.T. Walters, D. R. Buxton, Switchgrass Biomass Production in the Midwest USA: Harvest and Nitrogen Management. Agronomy Journal 2002; 94:413-420.

45. A. Teel, S. Barnhard, G. Miller, Management Guide for the Production of Switchgrass for biomass Fuel Production in Southern Iowa, PM 1710, Iowa State University Extension, Revised May 2003. Available at: http://www.extension.iastate.edu/Publications/PM1710.pdf.

46. J. Lawrence, J. Cherney, P. Barney, Q. Ketterings, Establishment and Management of Switchgrass, Fact Sheet 20, Agronomy Fact Sheets, Cornell University Cooperative Extension, 2006. Available at: http://nmsp.css.cornell.edu/publications/factsheets/factsheet20.pdf

47. L. Rinehart, Switchgrass as a Bioenergy Crop, A Web Publication of ATTRA - National Sustainability Agriculture Information Service (www.attra.ncat.org), 2006. Available at www.attra.ncat.org/attra-pub/pdf/switchgrass.pdf.

48. D.J. Parrish, D.D. Wolf, J.H. Fike, W.L. Daniels, Switchgrass as a Biofuels Crop for the Upper Southeast: Variety Trials and Cultural Improvements - Final Report for 1997 to 2001, ORNL/SUB-03-19XSY163/01, Oak Ridge National Laboratory, Oak Ridge, Tennessee, 2003. Available at: http://bioenergy.ornl.gov/main.aspx.

49. J. H. Reynolds, C.E. Sams, H.A. Fribourg, Photosynthesis and Forage Quality of Tall Fescue and Switchgrass, TEN00105 University of Tennessee, Department of Plant Sciences - Recent Findings on website. 2000. Available at http://plantsciences.utk.edu/sams_ad421_2000.htm.

50. W.E. Thomason, W.R. Raun, G.V. Johnson, C.M. Taliaferro, K.W. Freeman, K.J. Wynnm, R.W. Mullen. Switchgrass Response to Harvest Frequency and Time and Rate of Applied Nitrogen. Journal of Plant Nutrition 2004; 27:1199-1226.

51. G.T. Byrd and P.A. May, II, Physiological Comparisons of Switchgrass Cultivars Differing in Transpiration Efficiency, Crop Science 40: 1271-1277, 2000.

52. D.G. De La Torre Ugarte, M.E. Walsh, H. Shapouri, S.P. Slinsky The Economic Impacts of Bioenergy Crop Production on U.S. Agriculture, U.S. Department of Agriculture, Office of Chief Economist, Office of Energy Policy and New Uses, Agricultural Economic Report Number 816, February 2003. Available at http://www.usda.gov/oce/reports/energy/index.htm.

53. D.D. Wolf and D.A. Fiske, Planting and Managing Switchgrass for Forage, Wildlife, and Conservation, Publication 418-013, Virginia Cooperative Extension, 1995. Available at: http://www.ext.vt.edu/pubs/forage/418-013/418-013.html.

54. A. Teel, S. Barnhard, Switchgrass Seeding Recommendations for the Production of biomass Fuel in Southern Iowa, PM 1773, Iowa State University Extension, Revised May 2003. Available at: http://www.extension.iastate.edu/Publications/PM1773.pdf. 
55. W. Ocumpaugh, M. Hussy, J. Read, J. Muir, F. Horns, G. Evers, K. Cassida, B. Venuto, J. Grichar, C. Tishchler, Evaluation of Switchgrass Cultivars and Cultural Methods for Biomass Production in the South Central U.S.- Consolidated Report 2002, ORNL/SUB-0319XSY091C/01, Oak Ridge National Laboratory, Oak Ridge, Tennessee, 2003. Available at: http://bioenergy.ornl.gov/main.aspx (search by author).

56. B.V. Conger, Development of In Vitro Systems for Switchgrass (Panicum virgatum): Final Report for 1992 to 2002, ORNL/SUB-02-11XSY161/01, Oak Ridge National Laboratory, Oak Ridge, Tennessee, 2002. Available at: http://bioenergy.ornl.gov/main.aspx.

57. B. Nyoka, P. Jeranyama, V. Owens, A. Boe, M. Moechnig, Management Guide for Biomass Feedstock Production from Switchgrass in the Northern Great Plains, SGINC2-07, North Central Sun Grant Center, South Dakota State Unive5rsity, Brookings, SD 57007, June 2007. Available at: http://agbiopubs.sdstate.edu/articles/SGINC2-07.pdf.

58. D.J. Parrish, J.H. Fike, The Biology and Agronomy of Switchgrass for Biofuels, Critical Reviews in Plant Sciences 2005; 24: 423-459.

59. S.B. McLaughlin, D.G. De La Torre Ugarle, C.T. Garten, Jr., L.R. Lynd, M.A. Sanderson, V.R. Tolbert, D.D. Wolf. High Value Renewable Energy from Prairie Grasses, Environmental Sciences and Technology 36:2122-2129, 2002.

60. P.C. Hipple and M.D. Duffy, Farmers' motivations for Adoption of Switchgrass, In: Trends in new crops and new uses, J. Janick and A. Whipkey (eds), ASHS Press, Alexandria, VA. Also available at: http://www.hort.purdue.edu/newcrop/ncnu02/pdf/duffy-252.pdf.

61. P.R. Adler, M.A. Sanderson, A.A. Boateng, P.J. Weimer, J.G. Hans-Joachim, Biomass Yield and Biofuel Quality of Switchgrass Harvested in Fall or Spring. Agronomy Journal 2006; 98:1518-1525. 


\section{Appendix A. AUBURN UNIVERSITY YIELD RESULTS}

Dry matter yields of herbaceous species from 1985 to 1989 at four locations in Alabama analyzed separately for each location in each year (table scanned from Auburn final report ${ }^{(13)}$.

\begin{tabular}{|c|c|c|c|c|c|c|c|c|c|}
\hline Year & $\operatorname{Loc} \star$ & \multicolumn{2}{|c|}{$\begin{array}{c}\text { Annuals } \\
\text { Pearl } \\
\text { Sweet millet/ } \\
\text { Sorghum Corn a }\end{array}$} & Warm-season & n species & $\begin{array}{l}\text { Bermuda- } \\
\text { grass }\end{array}$ & $\begin{array}{c}\text { Sericea } \\
\text { Lespedeza }\end{array}$ & \begin{tabular}{l} 
Cool-seaso \\
Annual \\
\hdashline...-
\end{tabular} & $\begin{array}{c}\text { on species } \\
\text { Perennial } \\
\text { Tall } \\
\text { Fescue }\end{array}$ \\
\hline 1985 & $\begin{array}{r}\text { LCP } \\
\text { UCP } \\
\text { PM } \\
\text { SM } \\
\text { Mean }\end{array}$ & $\begin{array}{l}21.37 \mathrm{a}+ \\
-2 . .8 \\
16.89 \mathrm{a} \\
15.52 \mathrm{a} \\
17.93 \mathrm{H}\end{array}$ & $\begin{array}{l}11.83 \mathrm{~b} \\
13.55 \mathrm{a} \\
16.37 \mathrm{a} \\
10.98 \mathrm{~b} \\
13.18\end{array}$ & $\begin{array}{l}\ldots .80 \\
10 . \\
\ldots \ldots\end{array}$ & $\begin{array}{l}0.44 \mathrm{~b} \\
5.66 \mathrm{~b} \\
3.66 \mathrm{c} \\
2.44\end{array}$ & $\begin{array}{l}\ldots \ldots \\
1.88 \mathrm{~d} \\
0.47\end{array}$ & $\begin{array}{l}5.64 \mathrm{~b} \\
4.21 \mathrm{c} \\
2.46\end{array}$ & $\begin{array}{l}\cdots \ldots \\
\cdots \ldots \\
\cdots \ldots \\
\cdots \ldots\end{array}$ & $\begin{array}{l}\cdots \ldots \\
\ldots \ldots \\
\ldots \ldots \\
\ldots \ldots\end{array}$ \\
\hline 1986 & $\begin{array}{l}\text { LCP } \\
\text { UCP } \\
\text { PM } \\
\text { SM } \\
\text { Mean }\end{array}$ & $\begin{array}{r}6.75 \mathrm{a} \\
23.59 \mathrm{a} \\
9.48 \mathrm{a} \\
8.85 \mathrm{a} \\
12.17\end{array}$ & $\begin{array}{l}3.14 b \\
5.17 \mathrm{~d} \\
6.46 \mathrm{bc} \\
3.55 \mathrm{bc} \\
4.58\end{array}$ & $\begin{array}{l}\ldots \ldots \\
11.61 b \\
\ldots \ldots\end{array}$ & $\begin{array}{l}1.52 \mathrm{bc} \\
6.63 \mathrm{c} \\
8.22 \mathrm{ab} \\
4.19 \mathrm{bc} \\
5.14\end{array}$ & $\begin{array}{l}1.01 \mathrm{c} \\
4.15 \mathrm{~d} \\
3.33 \mathrm{~d} \\
2.94 \mathrm{c} \\
2.86\end{array}$ & $\begin{array}{l}1.28 \mathrm{c} \\
4.66 \mathrm{~d} \\
5.96 \mathrm{c} \\
4.64 \mathrm{~b} \\
4.14\end{array}$ & $\begin{array}{l}7.51 \mathrm{a} \\
4.97 \mathrm{~d} \\
7.02 \mathrm{bc} \\
3.29 \mathrm{c} \\
5.70\end{array}$ & $\begin{array}{l}2.59 \mathrm{e} \\
2.31 \mathrm{~d} \\
1.09 \mathrm{~d} \\
2.00\end{array}$ \\
\hline 1987 & $\begin{array}{l}\text { LCP } \\
\text { UCP } \\
\text { PM } \\
\text { SM } \\
\text { Mean }\end{array}$ & $\begin{array}{l}0.18 \mathrm{~b} \\
1.81 \mathrm{bc} \\
3.70 \mathrm{bc} \\
9.51 \mathrm{a} \\
3.80\end{array}$ & $\ldots$ & $\begin{array}{l}2.87 \mathrm{abc} \\
\ldots \ldots \\
\ldots \ldots\end{array}$ & $\begin{array}{l}2.87 \mathrm{ab} \\
4.78 \mathrm{ab} \\
7.97 \mathrm{a} \\
5.69 \mathrm{bc} \\
5.33\end{array}$ & $\begin{array}{l}4.95 \mathrm{a} \\
5.12 \mathrm{a} \\
5.43 \mathrm{ab} \\
7.21 \mathrm{ab} \\
5.68 .\end{array}$ & $\begin{array}{l}5.68 \mathrm{a} \\
4.65 \mathrm{ab} \\
5.35 \mathrm{ab} \\
5.18 \mathrm{bc} \\
5.22\end{array}$ & $\begin{array}{l}3.84 \mathrm{bc} \\
2.46 \mathrm{~d} \\
3.15\end{array}$ & $\begin{array}{l}5.89 \mathrm{a} \\
4.93 \mathrm{ab} \\
3.44 \mathrm{~cd} \\
4.75\end{array}$ \\
\hline 1988 & $\begin{array}{l}\text { LCP } \\
\text { UCP } \\
\text { PM } \\
\text { SM } \\
\text { Mean }\end{array}$ & $\begin{array}{r}3.78 \mathrm{c} \\
13.99 \mathrm{a} \\
14.43 \mathrm{a} \\
8.25 \mathrm{a} \\
10.11\end{array}$ & $\begin{array}{l}0.65 \mathrm{~b} \\
0.00 \mathrm{c} \\
1.14 \mathrm{~b} \\
5.89 \mathrm{~b} \\
1.92\end{array}$ & $\begin{array}{l}7.01 \mathrm{~b} \\
\ldots \ldots \\
\ldots \ldots\end{array}$ & $\begin{array}{l}6.99 \mathrm{ab} \\
8.38 \mathrm{~b} \\
6.50 \mathrm{~b} \\
6.87 \mathrm{~b} \\
7.19\end{array}$ & $\begin{array}{l}5.95 \mathrm{~b} \\
8.99 \mathrm{~b} \\
5.05 \mathrm{bc} \\
5.92 \mathrm{bc} \\
6.48\end{array}$ & $\begin{array}{l}7.86 \mathrm{a} \\
8.19 \mathrm{~b} \\
4.47 \mathrm{bc} \\
6.55 \mathrm{~b} \\
6.77\end{array}$ & $\begin{array}{l}3.57 \mathrm{c} \\
3.19 \mathrm{c} \\
3.68 \mathrm{bc} \\
1.24 \mathrm{~d} \\
2.92\end{array}$ & $\begin{array}{l}3.89 \mathrm{c} \\
3.34 \mathrm{c} \\
1.80 \mathrm{~d} \\
3.01\end{array}$ \\
\hline 1989 & $\begin{array}{l}\text { LCP } \\
\text { UCP } \\
\text { PM } \\
\text { SM } \\
\text { Mean }\end{array}$ & $\begin{array}{l}19.48 \mathrm{a} \\
4.76 \mathrm{c} \\
10.00 \mathrm{ab} \\
13.56 \mathrm{a} \\
11.95\end{array}$ & $\begin{array}{l}13.46 \mathrm{~b} \\
23.46 \mathrm{a} \\
12.12 \mathrm{a} \\
11.19 \mathrm{~b} \\
15.06\end{array}$ & $\begin{array}{l}4.82 c \\
\ldots \ldots \\
\ldots \ldots\end{array}$ & $\begin{array}{c}12.07 \mathrm{~b} \\
6.14 \mathrm{bc} \\
9.67 \mathrm{ab} \\
8.62 \mathrm{c} \\
9.12\end{array}$ & $\begin{array}{l}6.56 \mathrm{c} \\
6.15 \mathrm{bc} \\
5.92 \mathrm{bc} \\
8.20 \mathrm{c} \\
6.71\end{array}$ & $\begin{array}{l}8.25 \mathrm{bc} \\
8.01 \mathrm{~b} \\
5.60 \mathrm{c} \\
7.70 \mathrm{c} \\
7.39\end{array}$ & $\begin{array}{l}4.87 \\
3.07 \\
5.89 \\
3.60 \\
4.35\end{array}$ & $\begin{array}{r}8.98 \\
12.37 \\
13.00 \\
11.45\end{array}$ \\
\hline $\begin{array}{l}\mathrm{Lo} \\
\mathrm{re} \\
\mathrm{C} \\
\mathrm{A} \\
\mathrm{Y} \\
\mathrm{Me} \\
\mathrm{a} \\
\mathrm{St}\end{array}$ & $\begin{array}{l}\text { sent } t \\
\text { substa } \\
\text { ma Exp } \\
\text { s in } t \\
\text { compa } \\
=0.0 \\
\text { stical }\end{array}$ & $\begin{array}{l}\text { Coasta } 1 \\
\text { ons repre } \\
\text { iment Sta } \\
\text { s column } \\
\text { d within } \\
\text { level of } \\
\text { ifference }\end{array}$ & $\begin{array}{l}\text { ation Sys } \\
\text { are for } \\
\text { rows fol }\end{array}$ & $\begin{array}{l}\text { iographi } \\
\text { edmont a } \\
\text { ri mille } \\
\text { ed by th } \\
\text { e. }\end{array}$ & $\begin{array}{l}\text { in } 1985 \text { and } \\
\text { same letter }\end{array}$ & $\begin{array}{l}\text { d } 1986 \text { and } \\
\text { r are not }\end{array}$ & $\begin{array}{l}\text { iedmont (PM) } \\
\text { regions, } \\
\text { significant corn }\end{array}$ & $\begin{array}{l}\text { substation } \\
\text { and Sand } \\
\text { respective } \\
\text { in } 1988 \text { and } \\
\text { tly differe }\end{array}$ & $\begin{array}{l}\text { Mountain } \\
\text { ly, in the } \\
1989 . \\
\text { ent at }\end{array}$ \\
\hline
\end{tabular}


Appendix B. GEOPHYTA YIELD RESULTS

Mean dry matter yields for one harvest per season at three locations in Ohio for four years (scanned from Geophyta final report ${ }^{(14)}$.

\begin{tabular}{|c|c|c|c|c|c|}
\hline Species & Year & Site \# & Site \#2 & Site \#3 & LSD (0.05) \\
\hline Alfalfa & $\begin{array}{l}1986 \\
1987 \\
1988 \\
1989\end{array}$ & $\begin{array}{l}2.7 \\
4.2 \\
4.2 \\
4.6\end{array}$ & $\begin{array}{l}1.7 \\
3.8 \\
3.2 \\
4.2\end{array}$ & $\begin{array}{l}2.0 \\
3.8 \\
3.3 \\
4.3\end{array}$ & $\begin{array}{l}\text { Site: } 0.5 \\
\text { Year: } 0.4\end{array}$ \\
\hline Timothy & $\begin{array}{l}1986 \\
1987 \\
1988 \\
1989\end{array}$ & $\begin{array}{l}3.8 \\
4.7 \\
3.6 \\
4.9\end{array}$ & $\begin{array}{l}3.6 \\
3.8 \\
3.1 \\
5.4\end{array}$ & $\begin{array}{l}3.2 \\
3.2 \\
2.5 \\
4.8\end{array}$ & $\begin{array}{l}\text { Site: } 0.9 \\
\text { Year: } 0.7\end{array}$ \\
\hline Switchgrass & $\begin{array}{l}1986 \\
1987 \\
1988 \\
1989\end{array}$ & $\begin{array}{l}5.3 \\
4.7 \\
4.6 \\
9.0\end{array}$ & $\begin{array}{l}5.7 \\
4.1 \\
3.9 \\
7.7\end{array}$ & $\begin{array}{l}3.7 \\
3.0 \\
3.4 \\
7.7\end{array}$ & $\begin{array}{l}\text { Site: } 1.2 \\
\text { Year: } 0.9\end{array}$ \\
\hline Tall fescue & $\begin{array}{l}1986 \\
1987 \\
1988 \\
1989\end{array}$ & $\begin{array}{l}5.1 \\
5.1 \\
3.6 \\
5.2\end{array}$ & $\begin{array}{l}* \\
\text { * } \\
\text { * } \\
\text { * }\end{array}$ & $\begin{array}{l}\star \\
3.6 \\
3.6 \\
5.1\end{array}$ & $\begin{array}{l}\text { Site: NS } \\
\text { Year: NS }\end{array}$ \\
\hline Birdsfoot trefoil & $\begin{array}{l}1986 \\
1987 \\
1988 \\
1989\end{array}$ & $\begin{array}{l}3.3 \\
6.7 \\
6.0 \\
4.8\end{array}$ & $\begin{array}{l}2.6 \\
6.7 \\
5.3 \\
4.9\end{array}$ & $\begin{array}{l}1.8 \\
5.9 \\
4.2 \\
4.5\end{array}$ & $\begin{array}{l}\text { Site: } 0.9 \\
\text { Year: } 0.7\end{array}$ \\
\hline Reed canarygrass & $\begin{array}{l}1986 \\
1987 \\
1988 \\
1989\end{array}$ & $\begin{array}{r}5.1 \\
7.1 \\
6.6 \\
10.3\end{array}$ & $\begin{array}{l}5.1 \\
6.0 \\
5.8 \\
9.0\end{array}$ & $\begin{array}{l}\star \\
\star \\
\star \\
\star\end{array}$ & $\begin{array}{l}\text { Site: NS } \\
\text { Year: } 1.1\end{array}$ \\
\hline Forage sorghum - FS25E & $\begin{array}{l}1986 \\
1987 \\
1988 \\
1989\end{array}$ & $\begin{array}{r}22.0 \\
17.9 \\
5.1 \\
4.3\end{array}$ & $\begin{array}{r}16.2 \\
21.0 \\
5.0 \\
7.6\end{array}$ & $\begin{array}{r}13.9 \\
17.1 \\
6.2 \\
4.9\end{array}$ & $\begin{array}{l}\text { Site: NS } \\
\text { Year: } 5.1\end{array}$ \\
\hline Forage sorghum - S214 & $\begin{array}{l}1986 \\
1987 \\
1988 \\
1989\end{array}$ & $\begin{array}{r}{ }^{\star} \\
20.7 \\
5.9 \\
6.3\end{array}$ & $\begin{array}{r}{ }^{\star} \\
20.2 \\
5.4 \\
9.4\end{array}$ & $\begin{array}{r}\star \\
25.7 \\
6.7 \\
5.6\end{array}$ & $\begin{array}{l}\text { Site: NS } \\
\text { Year: } 6.3\end{array}$ \\
\hline Rye + Sorghum $x$ sudan. & $\begin{array}{l}1986 \\
1987 \\
1988 \\
1989 \\
\end{array}$ & $\begin{array}{r}23.5 \\
24.3 \\
9.1 \\
14.9 \\
\end{array}$ & $\begin{array}{r}22.2 \\
21.0 \\
8.1 \\
18.1 \\
\end{array}$ & $\begin{array}{r}22.2 \\
19.0 \\
7.9 \\
12.4 \\
\end{array}$ & $\begin{array}{l}\text { Site: NS } \\
\text { Year: } 3.4\end{array}$ \\
\hline
\end{tabular}




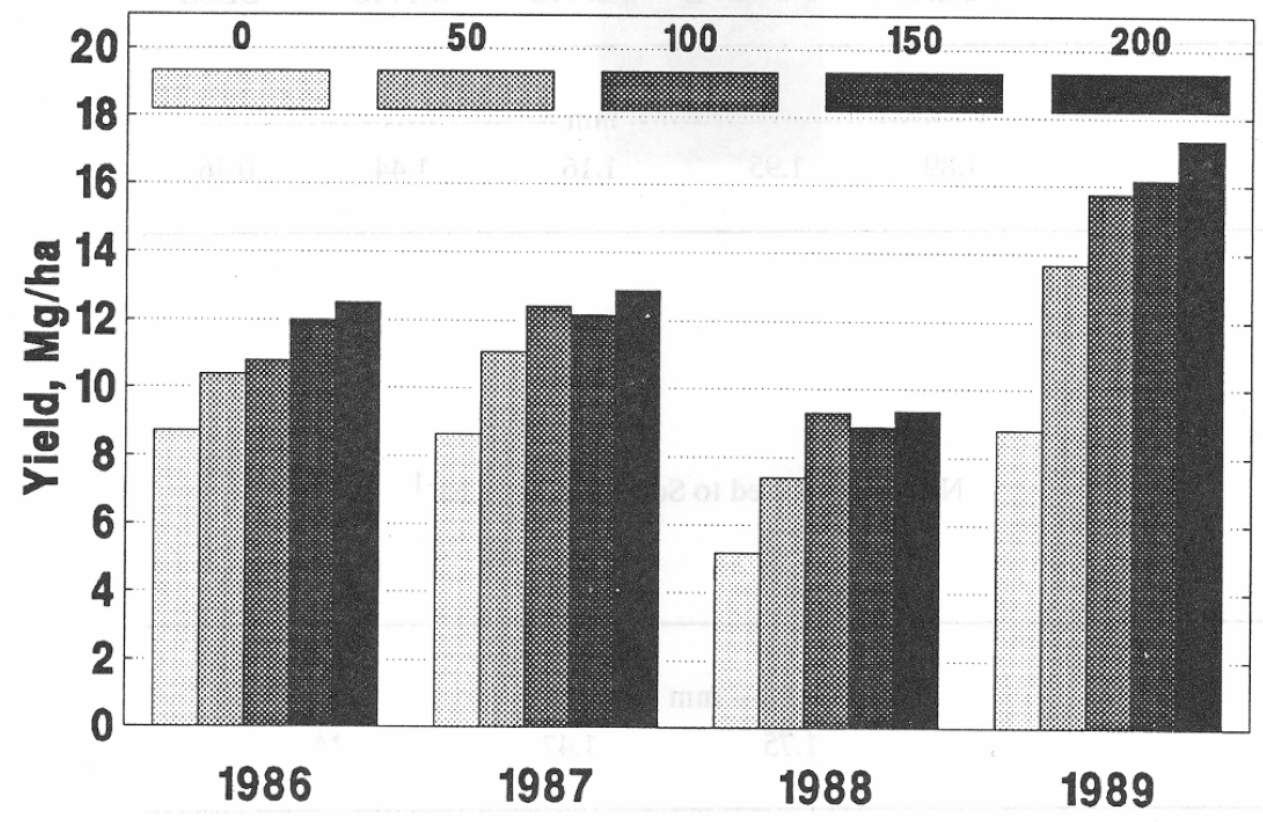

Figure C1. Switchgrass yield response to nitrogen fertilization $(0,50,150$, and $2000 \mathrm{~kg} \mathrm{~N} \mathrm{ha-1}$. Means of four replicates and one location in 1988 and 1989 (figure scanned from Cornell final report $^{(15)}$.

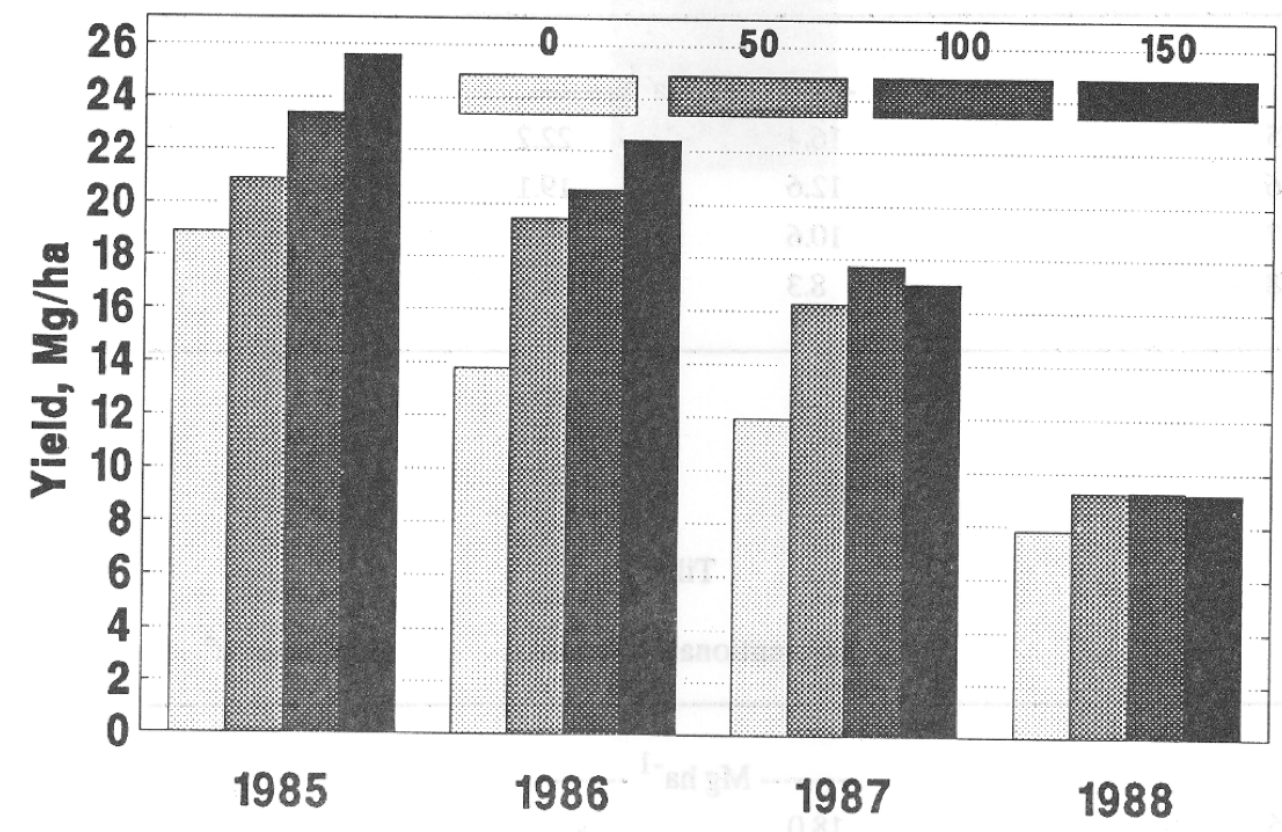

Figure C2 Sweet sorghum yield response to nitrogen fertilization $\left(0,50,100\right.$, and $150 \mathrm{~kg} \mathrm{~N} \mathrm{ha}^{-1}$ averaged over four replicates, four locations, and two tillage treatments (figure scanned from Cornell final report ${ }^{(15)}$. 


\section{Appendix D. IOWA STATE UNIVERSITY YIELD RESULTS}

Yield results for energy crops tested at Ames, a good cropland site and Chariton, a marginal cropland site $\left({ }^{17)}\right.$.

\begin{tabular}{|c|c|c|c|c|c|c|c|c|c|c|c|c|c|c|}
\hline \multicolumn{15}{|c|}{ Ames } \\
\hline YEAR & \multicolumn{6}{|c|}{ MONOCROP } & \multicolumn{2}{|c|}{ DOUBLE CROP } & \multicolumn{4}{|c|}{ ROTATION } & \multicolumn{2}{|c|}{ INTERCROP } \\
\hline $\begin{array}{l}\text { FERT } \\
\text { TRT }\end{array}$ & ALF & RCG & SWG & BBS & SS & SSH & SWS/R & SSH/R & CORN & SB & SWS & SWS/R & $\begin{array}{l}\text { ALF/ } \\
\text { SS }\end{array}$ & $\begin{array}{l}\text { RCG/ } \\
\text { SS }\end{array}$ \\
\hline $\mathrm{kgN} / \mathrm{ha}$ & \multicolumn{14}{|c|}{ 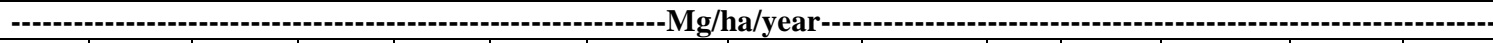 } \\
\hline 1988 & & & & & & & & & & & & & & \\
\hline 0 & & 5.97 & 8.1 & 6.8 & 15.1 & 14.4 & 9.1 & 9.6 & 7.7 & & & & & \\
\hline 70 & 6.1 & 5.2 & 7.7 & 5.7 & 15.3 & 13.6 & 11.7 & 11.9 & 8.6 & & & & & \\
\hline 140 & 6.1 & 5.5 & 8.3 & 6.4 & 17.5 & 14.6 & 12.0 & 14.0 & 11.3 & & & & & \\
\hline 280 & & 5.2 & 7.9 & 5.5 & 16.7 & 14.7 & 12.3 & 16.4 & 11.9 & & & & & \\
\hline \multicolumn{15}{|l|}{1989} \\
\hline 0 & & 3.0 & 5.0 & 6.2 & 16.3 & 13.1 & 10.1 & 9.3 & 10.5 & & & & & \\
\hline 70 & 11.1 & 5.8 & 8.0 & 6.9 & 16.1 & 14.7 & 15.8 & 15.0 & 15.1 & & 13.1 & 19.38 & 16.9 & 7.5 \\
\hline 140 & 12.9 & 7.9 & 8.3 & 6.4 & 15.3 & 16.3 & 19.0 & 19.1 & 17.8 & & 16.1 & 22.25 & 15.9 & 9.5 \\
\hline 280 & & 10.0 & 8.1 & 8.2 & 15.0 & 16.4 & 21.7 & 22.3 & 19.0 & & & & & \\
\hline \multicolumn{15}{|l|}{1990} \\
\hline 0 & & 5.8 & 7.2 & 10.7 & 11.4 & 10.8 & 11.6 & 9.1 & 11.1 & & & & & \\
\hline 70 & 10.2 & 7.2 & 11.6 & 10.7 & 15.3 & 11.4 & 15.7 & 12.8 & 15.1 & & 12.9 & 18.22 & 14.9 & 8.2 \\
\hline 140 & 12.1 & 10.3 & 10.6 & 11.4 & 20.7 & 15.3 & 19.6 & 15.1 & 16.6 & & 16.8 & 22.53 & 15.5 & 10.4 \\
\hline 280 & & 11.6 & 13.3 & 11.9 & 19.6 & 16.9 & 18.2 & 21.9 & 18.7 & & & & & \\
\hline \multicolumn{15}{|l|}{1991} \\
\hline 0 & & 4.6 & 4.9 & 7.3 & 13.5 & 14.3 & 19.9 & 8.9 & 7.3 & & & & & \\
\hline 70 & 10.1 & 6.8 & 11.2 & 8.3 & 16.7 & 16.3 & 14.2 & 12.0 & 10.2 & & 12.5 & 18.69 & 15.4 & 10.9 \\
\hline 140 & 10.3 & 7.9 & 10.3 & 7.7 & 16.5 & 16.7 & 20.5 & 14.2 & 11.5 & & 13.3 & 19.43 & 17.1 & 13.5 \\
\hline 280 & & 11.4 & 9.5 & 6.9 & 16.3 & 14.1 & 20.7 & 19.4 & 12.0 & & & & & \\
\hline \multicolumn{15}{|l|}{1992} \\
\hline 0 & & 2.9 & 7.2 & 8.4 & 8.6 & 11.5 & & & 8.5 & & & & & \\
\hline 70 & 9.3 & 4.5 & 13.8 & 11.1 & 17.7 & 15.1 & & & 7.2 & & 17.0 & & 11.1 & 7.3 \\
\hline 140 & 8.2 & 6.8 & 15.3 & 12.4 & 17.4 & 15.6 & & & 11.7 & & 18.4 & & 11.9 & 9.5 \\
\hline 280 & & 12.3 & 15.9 & 14.3 & 16.4 & 16.7 & & & 12.2 & & & & & \\
\hline \multicolumn{15}{|c|}{ Chariton } \\
\hline \multicolumn{15}{|l|}{1988} \\
\hline 0 & & & & & 17.8 & 12.8 & 10.3 & 10.2 & 7.7 & & & & & \\
\hline 70 & & & & & 16.8 & 14.1 & 9.9 & 11.1 & 8.6 & & & & & \\
\hline 140 & & & & & 17.9 & 13.9 & 9.6 & 11.4 & 11.3 & & & & & \\
\hline 280 & & & & & 19.3 & 14.0 & 11.4 & 12.5 & 11.9 & & & & & \\
\hline \multicolumn{15}{|l|}{1989} \\
\hline 0 & & & & 3.1 & 16.1 & 15.1 & 11.8 & 10.9 & 10.5 & & & & & \\
\hline 70 & 6.8 & & & 3.1 & 15.8 & 14.2 & 11.8 & 13.7 & 15.1 & & 10.4 & 13.81 & 2.3 & - \\
\hline 140 & 7.6 & & & 2.9 & 15.6 & 13.5 & 11.9 & 14.0 & 17.8 & & 12.1 & 15.53 & 2.5 & - \\
\hline 280 & & & & 3.0 & 16.4 & 15.7 & 12.8 & 14.2 & 19.0 & & & & & \\
\hline \multicolumn{15}{|l|}{1990} \\
\hline 0 & & 7.1 & 5.8 & 7.3 & 16.4 & 15.2 & 12.4 & 0.95 & 11.1 & & & & & \\
\hline 70 & 9.9 & 11.3 & 6.6 & 29.7 & 20.7 & 20.4 & 14.9 & 15.0 & 15.1 & & 13.7 & 20.95 & 3.8 & - \\
\hline 140 & 11.0 & 11.8 & 8.3 & 9.4 & 22.9 & 21.8 & 21.1 & 19.7 & 16.6 & & 19.5 & 26.72 & 3.9 & - \\
\hline 280 & & 13.1 & 8.3 & 9.4 & 19.1 & 22.7 & 26.6 & 24.1 & 18.7 & & & & & \\
\hline 1991 & & & & & & & & & & & & & & \\
\hline 0 & & 4.8 & 7.8 & 5.5 & 13.5 & 14.1 & 11.7 & 10.6 & 7.3 & & & & & \\
\hline 70 & 7.4 & 7.9 & 8.9 & 5.5 & 17.7 & 16.5 & 18.8 & 15.8 & 10.2 & & 17.2 & 24.41 & - & - \\
\hline 140 & 9.1 & 9.9 & 10.7 & 6.4 & 16.8 & 16.4 & 21.3 & 18.8 & 11.5 & & 20.2 & 25.29 & - & - \\
\hline 280 & & 10.5 & 10.9 & 5.5 & 17.2 & 16.9 & 23.6 & 21.5 & 12.0 & & & & & \\
\hline 1992 & & & & & & & & & & & & & & \\
\hline 0 & & 6.3 & 9.7 & 5.8 & 8.7 & 8.7 & & & 8.5 & & & & & \\
\hline 70 & 8.9 & 7.9 & 12.4 & 9.2 & 16.1 & 12.9 & & & 7.2 & & 14.2 & & & \\
\hline 140 & 6.7 & 10.9 & 15.8 & 10.5 & 16.7 & 12.6 & & & 11.7 & & 15.9 & & & \\
\hline 280 & & 12.8 & 17.4 & 12.8 & 16.5 & 17.0 & & & 12.2 & & & & & \\
\hline
\end{tabular}

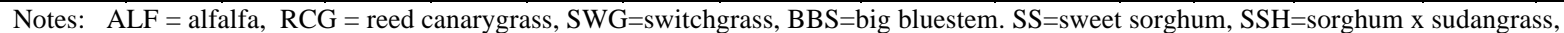

SWS/R=sweet sorghum doublecropped with winter rye, $\mathrm{SSH} / \mathrm{R}=$ sorghum $\mathrm{x}$ sudangrass double cropped with winter rye, $\mathrm{CORN}=$ corn total plant yield in a corn-soybean-sorghum three year rotation, in the corn-soybean-sorghum rotation, ALF/SS is intercrop of alfalfa with sweet sorghum, the sum of 3 harvests. RCG/SS involved the planting of sweet sorghum into a reed canarygrass stand, the sum of 3 harvests. 


\section{Appendix E. NORTH DAKOTA STATE UNIVERSITY YIELD RESULTS}

Mean biomass yields of several perennials at six North Dakota sites, averaged across years and Nitrogen levels, (scanned from North Dakota State University final report ${ }^{(18)}$ ).
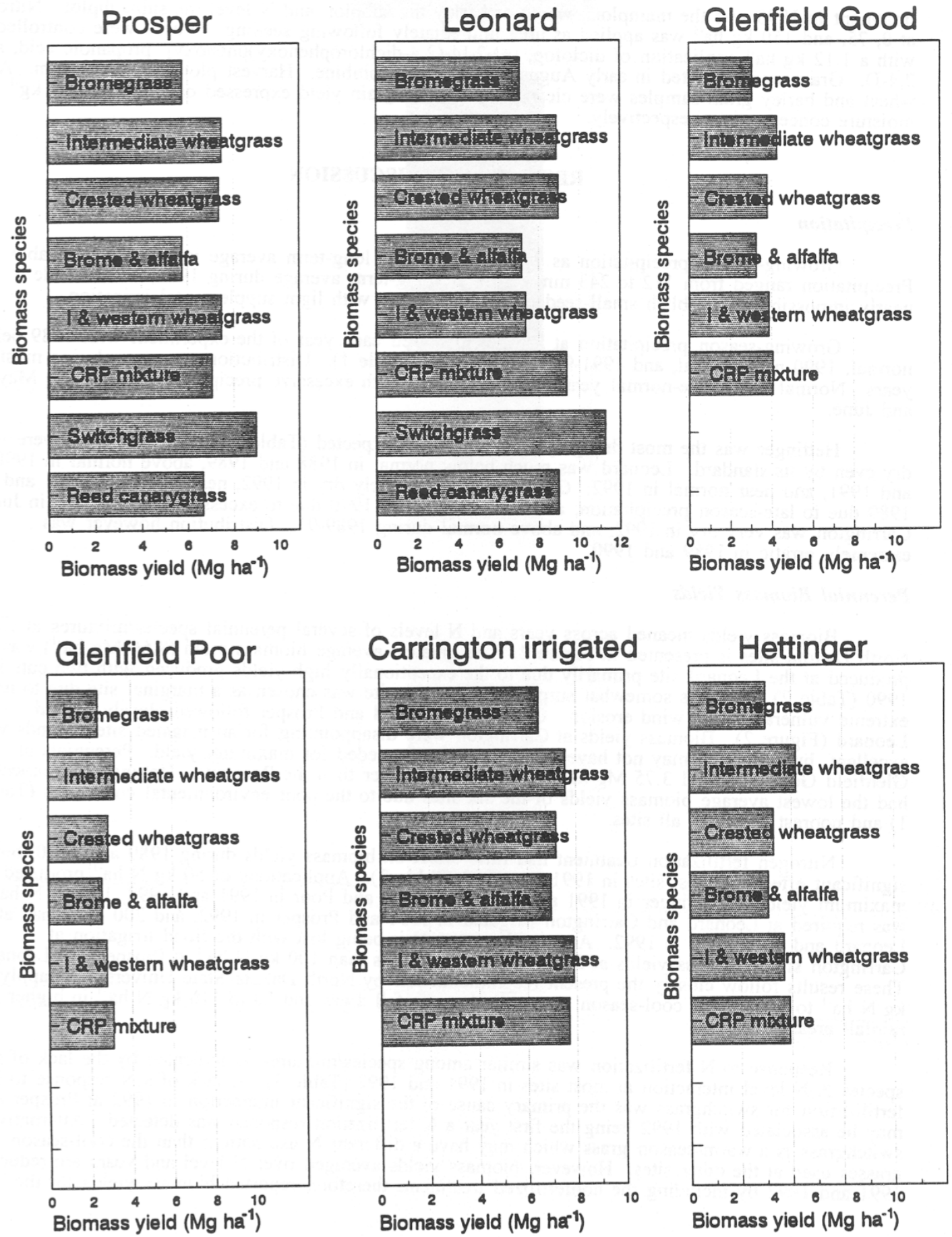


\section{INTERNAL DISTRIBUTION}
1. V.H. Dale
2-13. M.E. Downing
14. R.L. Graham
15. G.K. Jacobs
16. J.R. Mielenz
17. R.D. Perlack
18. M.J. Sale

\author{
19. S. Sokhansanj \\ 20. A.F. Turhollow \\ 21. T.O. West \\ 22. E.G. Wilkerson \\ 23-24. L.L. Wright \\ 25. ORNL Central Research Library \\ 26. ORNL Laboratory Records - RC
}

\section{EXTERNAL DISTRIBUTION}

27. J. Auyong, Oregon State University, 138 Strand Agriculture, Corvallis, OR 97331

28. J.A. Beaudry-Losique, U.S. Department of Energy, EE-2E, 1000 Independence Ave., SW, Washington, DC 20585

29. K.R. Craig, Department of Energy, Golden Field Office, MS 1501, 1617 Cole Blvd., Golden, CO 80401

30. J.J. Doolittle, South Dakota State University, Box 2120, SAE 221, Brookings, SD 57007-2141

31. T.R. Dutson, Oregon State University, 126 Strand Agriculture Hall, Corvallis, OR 97331-2212

32. A.M. Goss Eng, U.S. Department of Energy, EE-2E, 1000 Independence Ave., SW, Washington, DC 20585

33. J.E. Ferrell, U.S. Department of Energy, EE-2E, 1000 Independence Ave., SW, Washington, DC 20585

34. Z. Haq, U.S. Department of Energy, EE-2E, 1000 Independence Ave., SW, Washington, DC 20585

35. J.R. Hess, Idaho National Laboratory, P.O. Box 1625, 2525 Fremont Ave., Idaho Falls, ID 83415-2210

36. R.L. Huhnke, Oklahoma State University, 223 Agricultural Hall, Stillwater, OK 740786021

37. K.D. Kephart, South Dakota State University, ADM 130, Box 2201, Brookings, SD 57007

38. L. Neal, 8920 Stephens Road, Laurel, MD 20723

39. T. Nipp, 444 North Capitol Street, NW, Suite 715, Washington, DC 20001

40. G.R. Petersen, Department of Energy, Golden Field Office, MS 1511, 1617 Cole Blvd., Golden, CO 80401

41. T.G. Rials, The University of Tennessee, 2506 Jacob Drive, Knoxville, TN 37996-4570

42. L.J. Russo, U.S. Department of Energy, EE-2E, 1000 Independence Ave., SW, Washington, DC 20585

43. C.J. Rutzke, 120 Riley Robb Hall, Cornell University, Ithaca, NY 14853

44. S.G. Tagore, U.S. Department of Energy, EE-2E, 1000 Independence Ave., SW, Washington, DC 20585

45. L.P. Walker, 232 Riley-Robb Hall, Cornell University, Ithaca, NY 14853-5701 